http://dx.doi.org/10.12775/RT.2020.009

\title{
Michał Kurkowski*
}

\section{Rzeźba Chrystusa z tzw. kaplicy kopernikańskiej w kościele Świętojańskim w Toruniu}

\author{
The Sculpture of Christ from the So-called Copernican Chapel \\ at the St Johns' Church in Toruń \\ Skulptur Christi von der sog. Kopernikus-Kapelle \\ in der Johanniskirche in Thorn
}

\begin{abstract}
Streszczenie. W artykule omówiono rzeźbę Chrystusa znajdującą się w kościele parafialnym Starego Miasta Torunia w tzw. kaplicy kopernikańskiej. W 2018 r. została ona poddana pracom konserwatorskim, które pozwoliły na weryfikację dotychczasowych spostrzeżeń badawczych. Dzięki nim ustalono, że rzeźba powstała na przełomie XV/XVI w. pod wpływem warsztatów południowoniemieckich, a także, iż reprezentuje ona typ dewocyjnych przedstawień Umęczonego Chrystusa umieszczanych przy ścianach lub w szafach ołtarzowych.
\end{abstract}

* Autor jest absolwentem studiów z zakresu Ochrony Dóbr Kultury w Instytucie Zabytkoznawstwa i Konserwatorstwa WSP UMK w Toruniu. Studia doktoranckie ukończył w Katedrze Historii Sztuki i Kultury WNH UMK w Toruniu (2016). Jest autorem monografii pod tytułem Ryte i malowane dekoracje maswerkowe $w$ architekturze średniowiecznej na terytorium ziemi chetmińskiej. Studium typologiczno-formalne, t. 1-2, Torun 2017. Konsultował prace konserwatorskie w licznych obiektach zabytkowych. Jego zainteresowania badawcze dotyczą sztuki średniowiecznej i detalu architektonicznego na obszarze dawnego państwa krzyżackiego w Prusach. ORCID: 0000-0001-85096117 


\begin{abstract}
The article discusses the sculpture of Christ located in the parish church of the Old Town of Torun in the so-called Copernican Chapel. In 2018, it was subjected to conservation works, which allowed for the verification of the previous research observations. Thanks to them, it was established that the sculpture was created at the turn of the $15^{\text {th }}$ and $16^{\text {th }}$ centuries, under the influence of South German workshops, and that it represents a type of devotional representations of the Martyred Christ placed against walls or in altar cabinets.

Zusammenfassung. Im Artikel wird die Skulptur Christi in der Pfarrkirche der Altstadt von Thorn in der sog. Kopernikus-Kapelle präsentiert. Im Jahr 2018 wurde sie Konservierungsarbeiten unterzogen, die eine Verifizierung der bisherigen Forschungserkenntnisse ermöglichten. Dank ihnen wurde festgestellt, dass die Skulptur um die Wende des 15. Jh. unter dem Einfluss süddeutscher Werkstätten entstand, und auch, dass sie den Typ der Andachtsdarstellungen des Märtyrer Christi darstellt, die an Wänden oder in Altarschränken aufgestellt wurden.
\end{abstract}

Słowa kluczowe: rzeźba, Chrystus Umęczony, Toruń, dewocja, ikonografia

Keywords: sculpture, Martyred Christ, Toruń, devotion, iconography

Schlüsselwörter: Skulptur, Christus der Märtyrer, Thorn, Devotion, Ikonographie

W dawnym kościele parafialnym Starego Miasta Torunia, w tzw. kaplicy kopernikańskiej, pomiędzy oknami, na nowożytnej konsoli ustawiona jest wyjątkowo ciekawa późnogotycka rzeźba Chrystusa (il. 1), będąca częścią średniowiecznego wyposażenia tejże świątyni. Mimo że doczekała się licznych wzmianek w literaturze, nadal stanowi dobry przykład dzieła sztuki oczekującego na nowe kompleksowe omówienie. W realizacji tego zadania pomocne są prace konserwatorskie przeprowadzone w 2018 r. przez Joannę Ziemlewicz, dzięki którym dzieło to odzyskało swój pierwotny wygląd ${ }^{1}$. Konserwacja przywróciła figurze śred-

\footnotetext{
${ }^{1}$ Dziękuję pani konserwator dzieł sztuki Joannie Ziemlewicz za udostępniony materiał fotograficzny oraz dokumentacyjny. Pani profesor Elżbiecie Pileckiej składam serdeczne podziękowania za namowę do napisania niniejszego opracowania, a także za konsultacje merytoryczne i cenne podpowiedzi. Za możliwość wykonania zdjęć składam podziękowania księdzu prałatowi Markowi Rumińskiemu, proboszczowi kościoła pw.
} 
niowieczną formę: usunęła gipsowe dodatki (il. 2), ujawniła jakość modelunku rzeźbiarskiego, a to pozwala na nowo ocenić dzieło i jego miejsce w snycerskiej twórczości epoki późnego średniowiecza w Toruniu².

Stan badań nad rzeźbą Umęczonego Chrystusa z kościoła Świętojańskiego w Toruniu jest obszerny i wielowątkowy. Figura wymieniana była m.in. w opracowaniach syntetycznych, katalogowych, w artykułach poświęconych późnogotyckiej snycerce obszaru dawnych Prus Krzyżackich czy też w studiach dotyczących wyposażenia fary staromiejskiej w Toruniu i kościoła w Świerczynkach ${ }^{3}$. Przy jej omawianiu

św. Jana Chrzciciela i św. Jana Ewangelisty w Torunia, oraz księdzu Piotrowi Stefańskiemu, proboszczowi kościoła św. Jana Chrzciciela i św. Jana Ewangelisty w Świerczynkach.

${ }^{2}$ J. Ziemlewicz, Dokumentacja prac konserwatorskich i restauratorskich przy elementach wyposażenia wnętrza kaplicy tzw. Kopernikowskiej w Toruńskiej katedrze p.w. św. Jana Chrzciciela i św. Jana Ewangelisty, Torun 2017, s. 7, 12, 17-19, 21, 47, Archiwum Miejskiego Konserwatora Zabytków (dalej MKZ), sygn. 7311; E. Pilecka, Rzeźba Chrystusa w typie ikonograficznym Chrystusa Umęczonego - Mąż Boleści z kaplicy Kopernika w kościele św. Janów w Toruniu (obecnej katedrze), [w:] Dokumentacja prac konserwatorskich i restauratorskich przy elementach wyposażenia wnętrza kaplicy tzw. Kopernikowskiej w Toruńskiej katedrze p.w. św. Jana Chrzciciela i św. Jana Ewangelisty, red. J. Ziemlewicz, Toruń 2017, s. 29-46, MKZ, sygn. 7311.

${ }^{3}$ R. Heuer, Die Werke der bildenden Kunst und des Kunstgewerbes in Thorn bis zum Ende des Mittelalters, Mitteilungen des Coppernicus-Vereins für Wissenschaft und Kunst zu Thorn, H. 24, Thorn 1916, s. 106; Sz. Dettloff, Rzeźba polska do początku XVIII w., [w:] Wiedza o Polsce, t. II, Warszawa 1932, s. 560 n., ryc. 721; G. Chmarzyński, Toruń dawny i dzisiejszy, Toruń 1933, s. XVI, nr 55; G. Chmarzyński, Sztuka w Toruniu - zarys dziejów, [w:] Dzieje Torunia, red. K. Tymieniecki, Toruń 1933, s. 506; M. Walicki, Polska sztuka gotycka, Katalog wystawy, Warszawa 1935, s. 28, nr 78, tabl. XXXVI; T. Dobrowolski, Wystawa polskiej sztuki gotyckiej w Warszawie, Rocznik Krakowski, t. XXIV, Kraków 1935, s. 215; T. Mańkowski, Sprawozdania z posiedzeń za rok 1938, Posiedzenie z dnia 20 października 1938, praca pt. Do dziejów rzeźby późnogotyckiej (Miklas Haberschrak), Prace Komisji Historii Sztuki, t. VIII, z. II, 1946, s. 259; K. Zalska, Rzeźba późnogotycka w kościele parafialnym w Świerczynkach, [w:] Komunikaty na Sesję Naukowa poświęcona dziełom sztuki Pomorza, zorganizowana w 500-lecie Pokoju Toruńskiego, Torun 1966, s. 74; J. Kruszelnicka, Dwie gotyckie figury św. Barbary z kaplicy w Barbarce pod Toruniem, Rocznik Toruński, t. II, z. 3-4, 1967, s. 137; J. Kruszelnicka, Rzeźba i malarstwo, [w:] Kultura artystyczna ziemi chetmińskiej w czasach Kopernika, red. Z. Ciara, Torun 1973, s. 36, 38; J. Domasłowski, Wyposażenie wnętrza, [w:] Bazylika katedralna Świętych Janów w Toruniu, red. M. Biskup, Toruń 2003, s. 149-150; M. Woźniak, Przestrzeń liturgiczna kościoła p.w. św. Jana Chrzciciela i św. Jana Ewangelisty, [w:] Argumenta, articuli, quaestiones. Studia z historii sztuki średniowiecznej. Księga jubileuszowa dedykowana Marianowi 
skupiano się właściwie na kilku zasadniczych problemach: genezie formalnej i warsztatowej, datowaniu, ikonografii oraz lokalizacji figury w przestrzeni kościoła Świętojańskiego. Pierwsze wzmianki dotyczące rzeźby Umęczonego Chrystusa zamieszczone zostały w ogólnych opracowaniach dotyczących sztuki Torunia i regionu, autorstwa Reinholda Heuera $^{4}$, Szczęsnego Dettloffa ${ }^{5}$, a przede wszystkim Gwidona Chmarzyńskiego ${ }^{6}$. Poczynione przez tego ostatniego badacza spostrzeżenia co do datowania (koniec XV w.) oraz genezy warsztatowej (lokalnej) zostały zaakceptowane przez Michała Walickiego, Tadeusza Dobrowolskiego czy też Katarzynę Zalską ${ }^{7}$. Najwięcej uwagi poświęciła figurze Janina Kruszelnicka, zamieszczając obszerną notę w katalogu - Kultura artystyczna ziemi chetmińskiej w czasach Kopernika ${ }^{8}$. Sformułowane

Kutznerowi, red. A. Błażejewska, E. Pilecka, Torun 1999, s. 402-403; E. Pilecka, Kościót p.w. św. Jana Chrzciciela i św. Jana Ewangelisty w Toruniu w okresie średniowiecza jako wizualizacja świadomości społecznej, [w:] Dzieje i skarby kościoła Świętojańskiego w Toruniu, red. K. Kluczwajd, M. Woźniak, Toruń 2002, s. 172; A. Woziński, Artystyczne i ideowe aspekty późnogotyckiego krucyfiksu w pofranciszkańskim kościele Mariackim w Toruniu, [w:] Dzieje i skarby kościoła Mariackiego w Toruniu. Materiały z konferencji przygotowanej przez Toruński Oddział Stowarzyszenia Historyków Sztuki przy współpracy Instytutu Zabytkoznawstwa i Konserwatorstwa Uniwersytetu Mikołaja Kopernika (Toruń, 14-16 kwietnia 2005), red. naukowa K. Kluczwajd, Toruń 2005, s. 206, 220-221; E. Pilecka, Die Pfarrkirche St. Johannis zu Thorn als Abbild der sozialen Sinnesart des mittelalterlichen Bürgertums, [w:] Licht und Farbe in der mittelalterlichen Backsteinarchitektur des südlichen Ostseeraums (Studien zur Backsteinarchitektur), Bd. 7, hrsg. E. Badstübner, D. Schumann, Berlin 2005, s. 432; A. Woziński, Multiplicity and Unity. The Faces of Sculpture in Prussia between ca. 1450 and 1530, Acta Historiae Artium Balticae, Vol. 1, 2005, s. 65; A. Błażejewska, E. Pilecka, Sztuka średniowieczna, [w:] A. Błażejewska, K. Kluczwajd i inni, Dzieje sztuki Torunia, Torun 2009, s. 169; A. Woziński, On the Role of Engravings in Late Gothic Sculpture in Prussia, [w:] Kunst- und Kulturgeschichte im Baltikum. Studien zur Kunstgeschichte Kurlands, Homburger Gespräch 2008, H. 25, hrsg. L. O. Larsson, Kiel 2009, s. 22; J. Raczkowski, M. Jakubek-Raczkowska, Gotyckie rzeźby z kościoła w Świerczynkach. Przyczynek do badań nad średniowiecznym dziedzictwem Torunia, [w:] Stare i nowe dziedzictwo Torunia, red. J. Raczkowski, t. 1, Toruń 2013, s. 112.

${ }^{4}$ R. Heuer, Die Werke, s. 106

${ }^{5}$ Sz. Dettloff, Rzeźba polska, s. $560 \mathrm{n}$.

${ }^{6}$ G. Chmarzyński, Toruń dawny, s. XVI, nr 55; tenże, Sztuka Torunia, s. 506.

${ }^{7}$ M. Walicki, Polska sztuka, s. 28; T. Dobrowolski, Wystawa polskiej sztuki, s. 215; K. Zalska, Rzeźba późnogotycka, s. 137.

${ }^{8}$ J. Kruszelnicka, hasło: 18. Chrystus Bolesny - ryc. 22, [w:] Kultura artystyczna ziemi chetmińskiej w czasach Kopernika, red. Z. Ciara, Toruń 1973, s. 90-92. 
tam tezy o pochodzeniu i pierwotnym przeznaczeniu rzeźby, typie ikonograficznym, genezie wykonującego ją warsztatu oraz datowaniu stanowią właściwie punkt wyjścia dalszych studiów nad tym obiektem. Rzeźba wzmiankowana była również w opracowaniach dotyczących wyposażenia kościoła Świętojańskiego, lokalizacji ołtarzy, ich nastaw i przekształceń, którym ulegały ${ }^{9}$.

O genezie artystycznej figury Chrystusa Umęczonego wypowiedział się po raz pierwszy szerzej Gwido Chmarzyński, uznając, iż jest to dzieło miejscowego, osiadłego już w Toruniu warsztatu ${ }^{10}$. Za dzieło lokalnej pracowni uznali rzeźbę także Michał Walicki, Tadeusz Dobrowolski i Katarzyna Zalska ${ }^{11}$. Do jej oeuvre włączano też datowaną na koniec XV w. grupę Pietas Domini z kościoła w Świerczynkach oraz rzeźbę Chrystusa Ukrzyżowanego z kościoła Panny Marii w Toruniu ${ }^{12}$. Na powiązania warsztatowe tych dzieł miały wskazywać ogólne cechy modelunku figur, takie jak delikatna budowa ciał, smukłość sylwetek, podobieństwa w kształcie twarzy i zarostu czy też uplastyczniona siatka żył w opracowaniu powierzchni rzeźbiarskiej ${ }^{13}$. Uważano, że pod względem formalnym twórca rzeźby Umęczonego Chrystusa zainspirowany był wzorami zachodnioeuropejskimi, wśród których dostrzegano wpływy południowoniemieckie ${ }^{14}$, ale też północnoniemieckie (westfalskie?) i niderlandzkie ${ }^{15}$. Wskazywano również na oddziaływania poszczególnych warsztatów i mistrzów, m.in. Mikołaja Haberschracka ${ }^{16}$ lub Hansa Multschera ${ }^{17}$. W ukształtowaniu figury - szczególnie w pozie - widziano wyraźną zależność formalną od wzorów graficznych - Israhela van s. 172 .

${ }^{9}$ M. Woźniak, Przestrzeń liturgiczna, s. 402-403; E. Pilecka, Kościót p.w. św. Jana,

${ }^{10}$ G. Chmarzyński, Toruń dawny, s. XVI, nr 55; tenże, Sztuka Torunia, s. 506.

${ }^{11}$ M. Walicki, Polska sztuka, s. 28; K. Zalska, Rzeźba późnogotycka, s. 137.

${ }^{12}$ K. Zalska Rzeźba późnogotycka, s. 74; A. Woziński, Artystyczne i ideowe, s. 220-221.

${ }^{13}$ J. Kruszelnicka, Chrystus Bolesny, s. 92; A. Woziński, Artystyczne i ideowe, s. 220.

${ }^{14}$ Sz. Dettloff, Rzeźba polska, s. 560; G. Chmarzyński, Sztuka Torunia, s. 506; M. Walicki, Polska sztuka, s. 28; T. Dobrowolski, Wystawa polskiej sztuki, s. 215; A. Woziński, Artystyczne i ideowe, s. 220.

${ }^{15}$ J. Kruszelnicka, Chrystus Bolesny, s. 90-92; M. Woźniak, Przestrzeń liturgiczna, s. 402; E. Pilecka, Kościót p.w. św. Jana, s. 172; A. Błażejewska, E. Pilecka, Sztuka średniowieczna, s. 169

${ }^{16}$ T. Mańkowski, Sprawozdania z posiedzeń, s. 259.

${ }^{17}$ A. Błażejewska, E. Pilecka, Sztuka średniowieczna, s. 169. 
Meckenema ${ }^{18}$, Mistrza E. S. ${ }^{19}$ bądź też rzeźb, jak np. Męża Boleści umieszczonego w środkowej szafie ołtarza pochodzącego z klasztoru Benedyktynek w Królewcu-Lipinkach ${ }^{20}$. Dotychczasowa literatura próbowała łączyć rzeźbę Chrystusa Umęczonego z lokalnym środowiskiem osiadłych już wykonawców, snycerzy toruńskich, wpisując ją w łańcuch stylowych i chronologicznych przemian lokalnego rzemiosła snycerskiego. Była to próba określenia specyfiki twórczości Torunia i ziemi chełmińskiej oraz poszukiwania „genius loci” danego obszaru ${ }^{21}$. Datowanie omawianej figury zamykane było w przedziale od końca XV do pierwszego/drugiego dziesięciolecia XVI w. Część badaczy podjęła próbę dokładniejszego wyznaczenia czasu jej powstania: Reinhold Heuer określił go na około $1500^{22}$, Michał Walicki na około $1495^{23}$, natomiast Gwido Chmarzyński na 1497 r., na co, jego zdaniem, wskazują podobieństwa pomiędzy figurą Chrystusa Umęczonego a rzeźbą Chrystusa Zmartwychwstałego znajdującą się w kościele Swiętojańskim, datowaną precyzyjnie dzięki wyrytej na cokole dacie ${ }^{24}$. Starsze publikacje powtarzają te dawne ustalenia ${ }^{25}$, nowsze zaś datują figurę ogólnie na przełom XV/XVI w. (wkrótce po $1500 \mathrm{r}$.) ${ }^{26}$. Badacze próbowali jednocześnie określić pierwotną lokalizację rzeźby w przestrzeni fary staromiejskiej, wskazując, iż znajdowała się ona albo w kaplicy szyperskiej w tzw. „starym ołtarzu” - altare vetustum, albo też w zwieńczeniu ołtarza szafiastego Świętej Rodziny, stojącym przy północno-wschodnim filarze, ewentualnie w ołtarzu Korony Cierniowej lub w ołtarzu w kaplicy

${ }^{18}$ G. Chmarzyński, Sztuka Torunia, s. 506.

${ }^{19}$ A. Woziński, Artystyczne i ideowe, s. 221; tenże, On the Role of Engravings, s. 22.

${ }^{20}$ A. Woziński, Multiplicity and Unity, s. 65.

${ }^{21}$ G. Chmarzyński, Sztuka Torunia, s. 469-544; E. Pilecka, Dzieje sztuki Toruniastare i nowe ujęcia problemu. Refleksje na marginesie opracowań sztuki miasta profesora Gwidona Chmarzyńskiego, [w:] Gwido Chmarzyński i jego dzieło Sztuka w Toruniu, red. E. Okoń, Toruń 2014, s. 29-44.

${ }^{22}$ R. Heuer, Die Werke, s. 106; A. Woziński, On the Role of Engravings, s. 22.

${ }^{23}$ M. Walicki, Polska sztuka, s. 28.

${ }^{24}$ G. Chmarzyński, Toruń dawny, s. XVI, nr 55; tenże, Sztuka Torunia, s. 506.

25 T. Dobrowolski, Wystawa polskiej szuki, s. 215; Sz. Dettloff, Rzeźba polska, s. 560; K. Zalska, Rzeźba późnogotycka, s. 137.

${ }^{26}$ J. Domasłowski, Wyposażenie wnętrza, s. 149; M. Woźniak, Przestrzeń liturgiczna, s. 403; E. Pilecka, Kościót p.w. św. Jana, s. 172; A. Błażejewska, E. Pilecka, Sztuka średniowieczna, s. 169. 
Bożego Ciała. Sądzono także, że pełniła funkcję samodzielnej rzeźby dewocyjnej ${ }^{27}$. Pobieżnie $\mathrm{w}$ dotychczasowej literaturze traktowany był problem precyzyjnego określenia, do jakiego typu ikonograficznego możemy zaliczyć toruńską rzeźbę Chrystusa. Tę kwestię omówiła dotychczas szerzej jedynie Kruszelnicka ${ }^{28}$.

Mimo tych licznych wzmianek, wiele kwestii odnoszących się do tytułowej figury nie znalazło pełnego omówienia, na co wpływ miały z pewnością późniejsze nowożytne uzupełnienia znacznych partii figury zaprawą gipsową, a także przemalowania karnacji oraz pokrycie perizonium srebrną folią ${ }^{29}$. W niniejszym opracowaniu postaramy się określić genezę formy artystycznej figury - uczytelnionej w trakcie ostatnich prac konserwatorskich - i wskazać pierwotne jej zlokalizowanie oraz funkcję. Pomocne będą odsłonięte w czasie prac konserwatorskich szczegóły modelunku rzeźbiarskiego i warstwy oryginalnej polichromii. Osobnym zagadnieniem, któremu również postaramy się przyjrzeć, jest określenie typu ikonograficznego rzeźby.

Figurę stojącego Umęczonego Chrystusa wykonano z drewna lipowego $^{30}$. Mierzy ona $1,20 \mathrm{~m}$ (z podstawą $1,26 \mathrm{~m}$ ). Rzeźba jest półplastyczna; od tyłu silnie wydrążona - cały tył głowy, ramiona, korpus, prawe przedramię i część lewego przedramienia. Od bioder drążenie sięga aż do połowy lewego uda ${ }^{31}$. To nadaje figurze fizyczną lekkość, przy głębokim, plastycznym modelunku bryły w widoku frontalnym. Takie opracowanie świadczy jednocześnie, że przeznaczona była przede wszystkim do oglądu en face. Głębokie wydrążenie korpusu nie osłabiało materiału (wycięto twardziel z kloca drewna, pozostawiając biel,

${ }^{27}$ J. Kruszelnicka, Chrystus Bolesny, s. 90-92; J. Domasłowski, Wyposażenie wnętrza, s. 149-150; M. Woźniak, Przestrzeń liturgiczna, s. 402-403; E. Pilecka, Kościót p.w.św. Jana, s. 172; A. Błażejewska, E. Pilecka, Sztuka średniowieczna, s. 169.

${ }^{28}$ J. Kruszelnicka, Chrystus Bolesny, s. 91.

${ }^{29}$ J. Kruszelnicka, Chrystus Bolesny, s. 90; J. Ziemlewicz, Dokumentacja prac konserwatorskich, s. 17-19, 21.

${ }^{30}$ Wcześniej uważano, że jest to drewno iglaste - J. Domasłowski, Wyposażenie wnętrza, s. 149, trafnie rozpoznała je jako drewno lipowe - J. Ziemlewicz, Dokumentacja prac konserwatorskich, s. 17.

${ }^{31}$ Przywrócono oryginalny kształt odwrocia, usuwając gipsową aranżację pleców, głowy z koroną cierniową, włosów, stóp i perizonium - J. Ziemlewicz, Dokumentacja prac konserwatorskich, s. 7, 17. Szczegółowy opis rzeźby - E. Pilecka, Rzeźba Chrystusa, s. 30-33. 


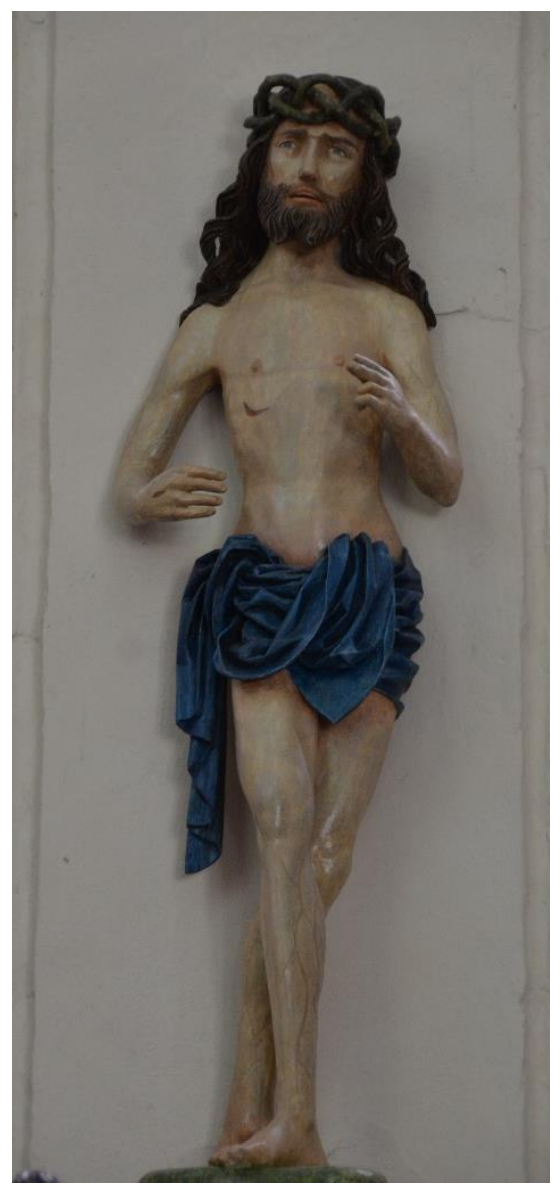

Il. 1. Rzeźba Chrystusa Umęczonego z tzw. kaplicy kopernikańskiej w kościele pw. św. Jana Chrzciciela i św. Jana Ewangelisty w Toruniu. Fot. M. Kurkowski

która nie pękała), nie ograniczyło też możliwości rzeźbiarskich i nie zwolniło wykonawcy ze starannego opracowania powierzchni. Korpus i perizonium zostały wykonane w całości z jednego kloca drewna, natomiast fragment perizonium (feston po prawej stronie figury) i ręce (od barków aż do dłoni) doklejono i umocowano na kołki najprawdopodobniej jeszcze przed ich rozrzeźbieniem ${ }^{32}$. Ustawienie figury na płaskiej

${ }^{32}$ J. Ziemlewicz, Dokumentacja prac konserwatorskich, s. 17. 
czworobocznej podstawie o zaokrąglonych bokach i uszkodzonym przez nieznaczne odłamanie prosto ściętym tyle świadczy o jej ekspozycji przy ścianie (filarze) lub przymocowaniu do tylnej ścianki skrzyni nastawy ołtarzowej ${ }^{33}$. W obydwu wypadkach wielkość rzeźby i jej opracowanie wskazywałyby na przewidziany jej ogląd raczej z bliska niż $\mathrm{z}$ daleka; kameralny, a nie grupowy. Bryła zachowuje cechy rzeźby trójwymiarowej, co podkreślają ujęcie postaci w wykroku oraz bardzo dynamiczny układ rąk, ,zagarniający” przestrzeń przed sobą i wokół siebie. Całej figurze nadano taneczny ruch o czytelnym rytmie rozwijającym się serpentynowo - nogi w zakroku, z prawą wysuniętą, a lewą skrzyżowaną za nią, z obydwiema stopami w pełni podpartymi i skierowanymi na zewnątrz, tworzą niejako dwie linie skręcającej się spirali, której ruch, łącząc się z korpusem, dopiero w nim zostaje wyhamowany. Wysunięte od łokci ręce stanowią jego uspokojoną kontynuację, a poruszenie wycisza się całkowicie w partii ramion i lekko uniesionej głowy Chrystusa. Rzeźbę ukształtowano z dbałością o poprawność budowy anatomicznej ciała, lecz bez przesadnego eksponowania śladów przebytej męki. Chrystus ukazany został z długimi nogami o zaznaczonych ścięgnach i o stopach $\mathrm{z}$ cienkimi długimi palcami. Tors opracowano jako wąski, rozrzeźbiony delikatnym rysunkiem mięśni i żeber ukazanych w sposób bliski prawdziwej budowie anatomicznej postaci ludzkiej (il. 1). Ręce są wyraźnie zgięte w łokciach, a ich układ oraz przykurcz palców dłoni mogą sugerować, że tkwiły w nich trzcina (widoczna w lewej dłoni na zdjęciach R. Heuera z $1916^{34}$ ), bicz lub kielich (choć żaden z tych atrybutów nie zachował się do dnia dzisiejszego). Głowę postaci, lekko pochyloną ku przodowi, okalają długie rozdzielone pasma pofalowanych włosów. Na twarzy wyrzeźbiono zarost w postaci krótkiej, rozdzielonej na osi brody. Biodra Chrystusa „owinięto” krótką, poprzeczną, bardzo plastycznie rozrzeźbioną tkaniną perizonium z czytelnymi łamanymi fałdami, modelowanymi także w formy widelcowe, małżowinowe i płaskie festony. Głowa figury osadzona została na krótkiej szyi przechodzącej $\mathrm{w}$ wąskie, spadziste ramiona. Pociągłej twarzy nadano

\footnotetext{
${ }^{33}$ Co dostrzegli: J. Kruszelnicka, Chrystus Bolesny, s. 90-92; M. Woźniak, Przestrzeń liturgiczna, s. 402-403; E. Pilecka, Kościót p.w. św. Jana, s. 172; A. Błażejewska, E. Pilecka, Sztuka średniowieczna, s. 169.

${ }^{34}$ R. Heuer, Die Werke, s. 106.
} 
charakterystyczne rysy i starannie wymodelowano naturalistycznie ujętą anatomię. Silnie zarysowana została dolna szczęka, szeroko rozstawione są otwarte oczy, patrzące przed siebie, z opadającymi ku skroniom kącikami. Podobny układ nadano krawędziom boleśnie uniesionych łuków brwiowych, schodzących się między brwiami fałdą w kształcie litery „V”. Nos jest prosty i długi, powiązany ze zmarszczką między brwiami. Usta, półotwarte, z wyraźnie opracowaną i wysuniętą ku przodowi tzw. rynienką podnosową, odsłaniają równe rzędy zębów. Górna warga jest mocniej zaznaczona i uniesiona. Głowę okalają długie - sięgające poniżej ramion - ażurowo ukształtowane pasma włosów; gęste i spiralnie skręcone, z wyraźnym graficznym opracowaniem poszczególnych pukli. Krótki zarost brody rozdziela się na osi na dwa symetryczne, delikatnie i niezbyt głęboko rozrzeźbione pasma. Na głowie tkwi nisko nasadzona na skronie, skręcona $\mathrm{z}$ grubych, przeplatających się dwóch wałków, ażurowa korona cierniowa, wyrzeźbiona oddzielnie. Perizonium ukazano jako przewiązane nisko na wąskich biodrach. Charakteryzuje je obfitość ukazanej tkaniny, która jest rozrzeźbiona jako zmięta („łamana”) i udrapowana poprzecznie szata, owijająca biodra i wywieszająca się kaskadowo-meandrycznym, ale płaskim festonem po prawej stronie figury oraz płaskim i trójkątnie zakończonym ,językiem" - po lewej. Perizonium rozrzeźbione jest przez wywinięte małżowinowo, budowane po linii łuku duże fałdy oraz przez krótkie, głębokie, małe fałdki opracowane „,widelcowo”, „drążone łyżeczkowo” i „,małżowinowo". Jest ono nimi gęsto pokryte. Te drobne, łamliwe fałdy nie przylegają do wolumenu rzeźby, lecz żyją własnym życiem. Są jakby wypchnięte od niej na zewnątrz, ku przodowi i zostały uformowane bez oddania iluzji ciężaru: „nadmuchane” i metalicznie sztywne. Przepaska biodrowa jest opracowana - mimo dużej masy oddanej tkaniny - jako krótka, bo przykrywająca tylko częściowo partię ud, poprzecznie naciągnięta i przynajmniej dwukrotnie przerzucona przez jej szerokość, o czym świadczą festony. W efekcie takiego ujęcia nogi figury ukazane zostały niemal w całej długości. Tors jest obły, miękko modelowany, z gładko opracowaną partią brzucha, z klatką piersiową o zaznaczonej budowie kostnej i oddanym układzie mięśni. Na obłym brzuchu zaznaczono płytką pionową bruzdę, od której odchodzą na boki wyrzeźbione partie mięśni w postaci wypukłych trzech pasów po każdej stronie klatki 
piersiowej, przechodzących w karbowane żebra. Klatka piersiowa jest nieznacznie szersza od bioder, z zaznaczonym zagłębionym mostkiem, a przy szyi z wyraźnymi kośćmi obojczykowymi. Nisko zaznaczone sutki są plastycznie aplikowane na powierzchni rzeźby. Wszystkie członki figury Chrystusa są długie, niemal rachityczne, a ich stawy wyoblone i miękko zarysowane. Cienkie ramiona zgięte w łokciach odtworzono realistycznie z zaznaczeniem stawów, mięśni, ścięgien i plastycznie oddanych krzyżujących się ze sobą żył. Z szerokich śródręczy wychodzą grube, rozpostarte i przykurczone w paliczkach dłonie (z wyjątkiem trzech wyprostowanych palców w lewej ręce). Palce uformowano jako prosto zakończone i zwężające się ku zagłębionym w materiale rzeźbiarskim szerokim paznokciom. Cienkie i długie nogi o wyodrębnionych mięśniach ud i łagodnie zarysowanych stawach kolanowych, z uwidocznionymi zarysami kości piszczelowych, wrzecionowatymi łydkami, są naturalistycznie ukształtowane. Wsparte zostały na dużych stopach z wystającą piętą i z długimi paliczkami palców o szerokich paznokciach. W sposób naturalistyczny rzeźbiarz ukazał drobne elementy budowy anatomicznej: ścięgna, paznokcie, sutki, siatkę żył itp. Delikatnie natomiast - bo jedynie w warstwie polichromii (w znacznym stopniu przetartej w warstwie oryginalnej) - zaznaczył znamiona męki, np. małą ranę w boku i na dłoniach. Precyzyjnie i różnorodnymi dłutami opracował włosy i zarost. Pierwotna polichromia przedstawia się następująco: karnacja ciała jasna, cielista, z błękitno-fioletowymi podmalowaniami, broda i włosy brunatne, usta różowe, oczy i brwi podkreślone przez czarne i brązowe linie, perizonium niebieskie - lapis-lazuli ${ }^{35}$, natomiast korona cierniowa ciemnozielona ${ }^{36}$.

Rzeźba jest - jak wyżej opisano - głęboko drążona od tyłu, niemal ażurowa, jeśli chodzi o ukształtowanie bryły rzeźbiarskiej. Pod względem grubości materiału, z którego została wykonana, można określić ją jako opracowaną „łupinowo”. Modelunek powierzchni rzeźbiarskiej

\footnotetext{
${ }^{35}$ Kolor niebieski perizonium jest powszechnie stosowaną barwą w sztuce średniowiecznej, np.: Ukrzyżowanie z Freising z XII w. - http://de.mittelalter.wikia.com/wiki/ Kruzifix; Ukrzyżowanie w Psałterzu francuskim, Paryż, 1228-1234, MS M.153 fol. 21r - http://ica.themorgan.org/manuscript/page/32/77091; Miniatura z przedstawieniem „Żywego krzyża" - https://oldenglishwordhord.com/tag/crucifixion/.

${ }^{36}$ J. Ziemlewicz, Dokumentacja prac konserwatorskich, s. 7, 18-19.
} 
świadczy o chęci oddania budowy anatomicznej, a także podkreślenia naturalizmu w oddaniu stawów, żył, znamion wycieńczenia. W rzeźbie ujawnia się więc dobrze ukazana materialna cielesność i dążenie do podkreślenia dynamiki formy. Tę ostatnią uzyskano poprzez przedstawienie kroczącej postaci Chrystusa, autonomię poszczególnych członków ciała i chaotyczność ruchów. Zróżnicowany i bogaty rysunek fałd wzmocnił dynamikę kompozycji rzeźbiarskiej, potęgując także wrażenie ruchu samej postaci ${ }^{37}$. Wzmogło to efekt „wychodzenia ku widzowi”, czyli zgodnie z intencją tematu - ku modlącemu się wiernemu. Obok krótkich, głębokich „widelcowych” i „drążonych łyżeczkowo” fałdek są także fałdy duże, wywinięte małżowinowo, budowane na linii łuku, oraz sztywny, prosty ,jęzor" pionowo wywieszonego końca perizonium. Jest to klasyczny repertuar form późnogotyckich, powszechnych w sztuce europejskiej od lat siedemdziesiątych XV stulecia - nawet do XVII w. Skłonność do naturalistycznego oddania szczegółów budowy anatomicznej i swoisty „humanizm” w ukazywaniu ludzkiej kondycji są także właściwe sztuce tej epoki.

Przyglądając się genezie stylistyczno-warsztatowej świętojańskiej figury Chrystusa Umęczonego należy zauważyć, że pod względem formalnym dzieło to jest związane z okresem rozwoju sztuki Torunia około $1500 \mathrm{r}^{38}$ - innym jednak etapem w dziejach rzeźby toruńskiej niż ten, który reprezentowały dzieła Mistrza Ołtarza św. Wolfganga i zależnych od niego kręgów wykonawców ${ }^{39}$. Świadczy o tym ów samodzielny ruch ciała (a nie tylko szat), miękkość opracowania rzeźbiarskiego partii korpusu, długich i szczupłych członków ciała, typ twarzy o indywidualnych, pociągłych rysach, modelunek ich detali, zarostu i włosów. Wydaje się, że toruńska rzeźba reprezentuje późnogotycki styl, odrzucający „wolfgangowskie” nawyki formalne, a poszukujący nowych rozwiązań i inspiracji. Za takim zakwalifikowaniem stylowym figury przemawia bardziej autonomiczne ,poruszenie” poszczególnych partii ciała Chrystu-

\footnotetext{
${ }^{37}$ E. Pilecka, Rzeźba Chrystusa, s. 30-31.

${ }^{38}$ Ogólnie o sztuce około 1500 r. w Toruniu: G. Chmarzyński, Sztuka Torunia, s. 484-485, 505-507; E. Pilecka, Kościół p.w. św. Jana, s. 168-176; A. Błażejewska, E. Pilecka, Sztuka średniowieczna, s. 153-185; E. Pilecka, Rzeźba Chrystusa, s. 33.

${ }^{39}$ Por. charakterystykę stylu Mistrza ołtarza św. Wolfganga w: J. Kruszelnicka, Dwie gotyckie figury, s. 132 n.; J. Kruszelnicka, Rzeźba i malarstwo, s. 28-45 - wraz $\mathrm{z}$ opisem formalnym rzeźby.
} 


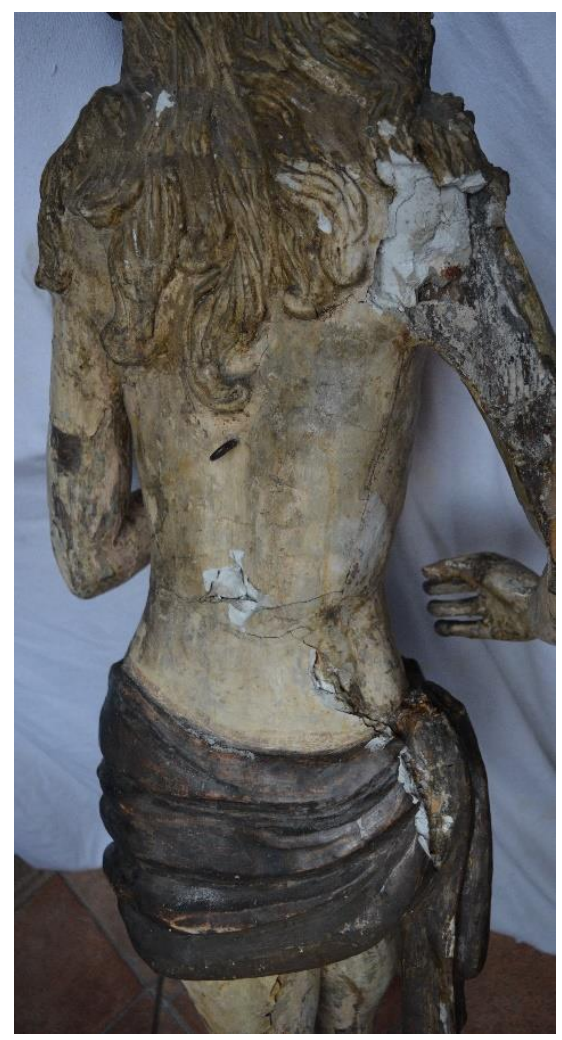

Il. 2. Tył rzeźby Chrystusa Umęczonego przed pracami konserwatorskimi. Fot. J. Ziemlewicz

sa, jak i sposób drapowania materii perizonium. Okres, o którym mowa, przypadał na przełom XV/XVI w. i dwa pierwsze dziesięciolecia XVI $\mathrm{w} .^{40}$ Tak też bywała najczęściej datowana przez badaczy toruńska figura Chrystusa Umęczonego ${ }^{41}$. Postrzegana była ona jednak jako dzieło

${ }^{40}$ J. Kruszelnicka, Rzeźba i malarstwo, s. 28-45; E. Pilecka, Rzeźba Chrystusa, s. 33.

${ }^{41}$ G. Chmarzyński, Toruń dawny, s. XVI; G. Chmarzyński, Sztuka Torunia, s. 506; M. Walicki, Polska sztuka, s. 28; T. Dobrowolski, Wystawa polskiej sztuki, s. 215; Sz. Dettloff, Rzeźba polska, s. 560; K. Zalska, Rzeźba późnogotycka, s. 137; J. Kruszelnicka, Chrystus Bolesny, s. 90-92; M. Woźniak, Przestrzeń liturgiczna, s. 403; E. Pilecka, Kościół p.w. św. Jana, s. 172; A. Błażejewska, E. Pilecka, Sztuka średniowieczna, s. 169. 
lokalne, inspirowane wzorami obcymi, a przede wszystkim wpływami westfalsko-niderlandzkimi ${ }^{42}$ lub też południowoniemieckimi ${ }^{43}$. Chcąc rozstrzygnąć genezę warsztatową rzeźby Chrystusa Umęczonego, należy przyjrzeć się twórczości tzw. Mistrza Krucyfiksu Franciszkańskiego (rzeźba z kościoła NMP w Toruniu, umieszczona na północnej ścianie nawy głównej, przy prezbiterium). Do oeuvre tegoż twórcy włączono także rzeźbę Pietas Domini z kościoła parafialnego w Świerczynkach oraz omawianą figurę Chrystusa (Chrystusa Umęczonego) ${ }^{44}$. To ostatnie dzieło uznawane było wręcz za wczesną pracę Mistrza lub jego zdolnego ucznia. Takiego stanowiska w sprawie proweniencji warsztatowej nie można jednak zaakceptować bez zastrzeżeń. Pomiędzy naszą rzeźbą a krucyfiksem franciszkańskim dostrzec można wprawdzie analogie polegające na podobnym uformowaniu perizonium (il. 3) (jako zmiętej tkaniny owijającej się nisko wokół bioder), ukształtowanym w obu rzeźbach przez małe fałdki. Analogicznie został potraktowany także krótki zarost o wyodrębnionych poszczególnych kosmykach, rozdzielony na osi brody na dwa symetryczne i niezbyt głęboko rozrzeźbione pasma. Oba dzieła charakteryzują się też delikatną budową ciała i odtworzoną z precyzją siatką żył ${ }^{45}$, ale dostrzec można jednak między nimi wyraźne różnice. Sama sylwetka figury Ukrzyżowanego z kościoła NMP w Toruniu w stosunku do Chrystusa Umęczonego z kościoła Świętojańskiego jawi się jako bardziej wychudzona, wyciągnięta, wręcz lancetowa w pionie (il. 1, 3). Twarz jest bardziej podłużna, ostrzej zarysowana, z wyodrębnioną kostną budową, o wyraźnie zapadniętych policzkach, dłuższym nosie i głęboko osadzonych oczodołach. W kształtowaniu włosów, które u Chrystusa franciszkańskiego tworzą zwartą, syntetyczną formę nałożoną na czerep głowy, także widać warsztatowe różnice opracowania. Korpus tej rzeźby został opracowany poprzez wyraźniejsze wydzielenie mostka i regularny układ żeber oraz ukazanie wyraź-

\footnotetext{
42 J. Kruszelnicka, Chrystus Bolesny, s. 90-92; M. Woźniak, Przestrzeń liturgiczna, s. 402; E. Pilecka, Kościót p.w. św. Jana, s. 172.

${ }^{43}$ Sz. Dettloff, Rzeźba polska, s. 560; G. Chmarzyński, Sztuka Torunia, s. 506; M. Walicki, Polska sztuka, s. 28; T. Dobrowolski, Wystawa polskiej sztuki, s. 215; M. Woźniak, Przestrzeń liturgiczna, s. 403; A. Woziński, Artystyczne i ideowe, s. 220.

${ }^{44}$ K. Zalska, Rzeźba późnogotycka, s. 72 n.; J. Kruszelnicka, Dwie gotyckie figury, s. 137; A. Woziński, Artystyczne i ideowe, s. 206.

${ }^{45}$ J. Kruszelnicka, Chrystus Bolesny, s. 92; A. Woziński, Artystyczne i ideowe, s. 220.
} 


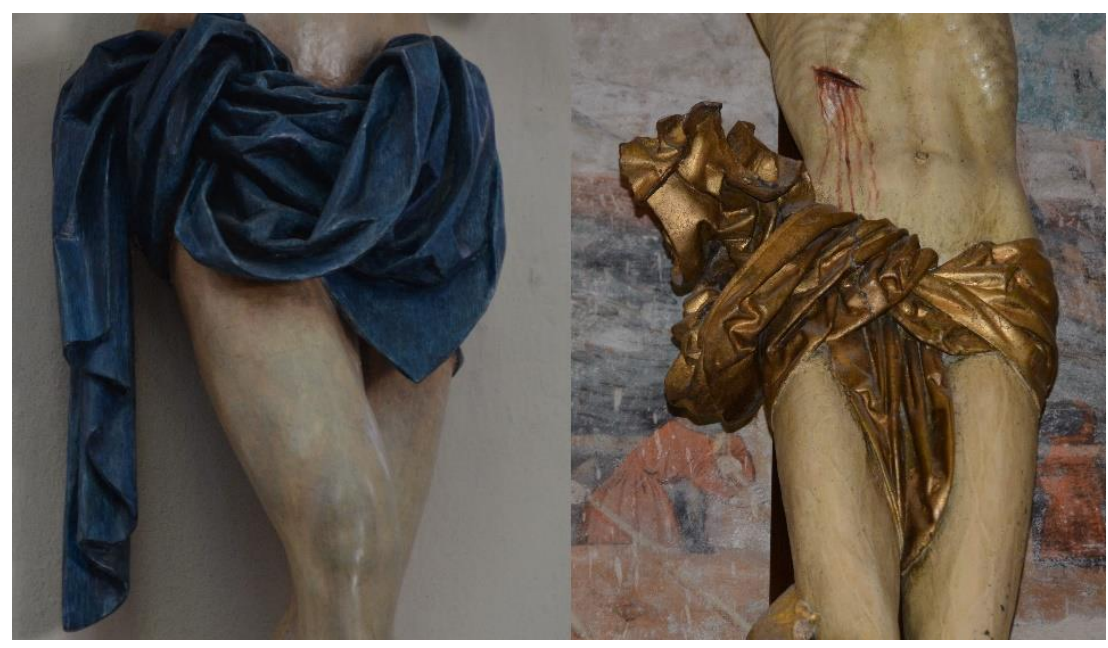

a

b

Il. 3. Perizonium Chrystusa: a - z kościoła pw. św. Jana Chrzciciela i św. Jana Ewangelisty w Toruniu, b - z kościoła pw. NMP w Toruniu. Fot. M. Kurkowski

nie zapadniętego brzucha. Drugie dzieło tzw. warsztatu franciszkańskiego - rzeźba z grupy Pietas Domini ze Świerczynek - dostarcza tylko kilku analogii w zestawieniu $\mathrm{z}$ interesującym nas zabytkiem (il. 1, 4). Analogicznie został ukształtowany korpus w obu przedstawieniach Chrystusa - jako zwarta bryła z płaskim i delikatnym rysunkiem żeber oraz mięśni brzucha. Za podobne możemy uznać także: zarost o wyodrębnionych poszczególnych kosmykach, rozdzielający się na osi na dwa pasma, włosy ukształtowane jako długie pukle o ażurowych prześwitach $^{46}$ czy siatkę żył. Również podobne są twarze o długim nosie, otwartych ustach i widocznych zębach. Do zasadniczych różnic pomiędzy nimi należy przede wszystkim syntetyczne potraktowanie szat w rzeźbie Pietas Domini ze Świerczynek, w której dominują płytkie fałdki oraz duże płaszczyzny. Wyjątkowo cienkie i wydłużone są w niej także członki ciała Chrystusa podtrzymywanego przez Boga Ojca. Trudno więc

\footnotetext{
${ }^{46}$ Widocznych w rzeźbie ze Świerczynek tylko u Boga Ojca.
} 


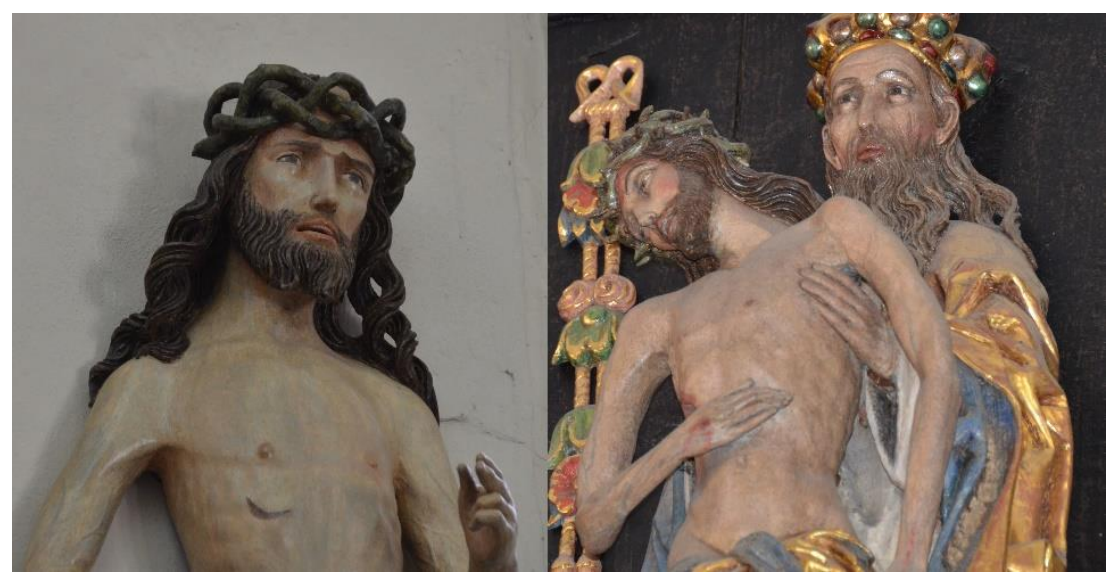

a

b

Il. 4. Korpus i głowa: a - Chrystusa z kościoła pw. św. Jana Chrzciciela i św. Jana Ewangelisty w Toruniu, b - rzeźby Pietas Domini z kościoła pw. św. Jana Chrzciciela i św. Jana Ewangelisty w Świerczynkach. Fot. M. Kurkowski

mówić o ścisłych zależnościach warsztatowych pomiędzy tymi zabytkami. Możemy jednak uznać, że w wymienionych powyżej dziełach dostrzec można analogie polegające na posłużeniu się podobnymi wzorcami i motywami w formowaniu bryły rzeźbiarskiej. Wyjątkowy i indywidualny styl twórcy tzw. Krucyfiksu Franciszkańskiego prawdopodobnie ukształtował się w kręgu sztuki flandryjskiej ${ }^{47}$. Wskazówką ku takiej atrybucji także dla rzeźby Trójcy Świętej ze Świerczynek są jej ikonograficzno-kompozycyjne powiązania $\mathrm{z}$ obrazem Mistrza z Flemalle o tej samej tematyce - oraz z dziełami grafiki niderlandzkiej z XV w., m.in. z tzw. Mistrzem Banderol ${ }^{48}$. Tymczasem dla figury Chrystusa Umęczonego z kościoła Świętojańskiego wiele bliższych analogii dostarczają

${ }^{47}$ J. Kruszelnicka, Rzeźba i malarstwo, s. 26-28; J. Domasłowski, Wyposażenie wnętrza, s. 150.

${ }^{48}$ K. Zalska, Rzeźba późnogotycka, s. 74-75; J. Kruszelnicka, Dwie gotyckie figury, s. 138. 


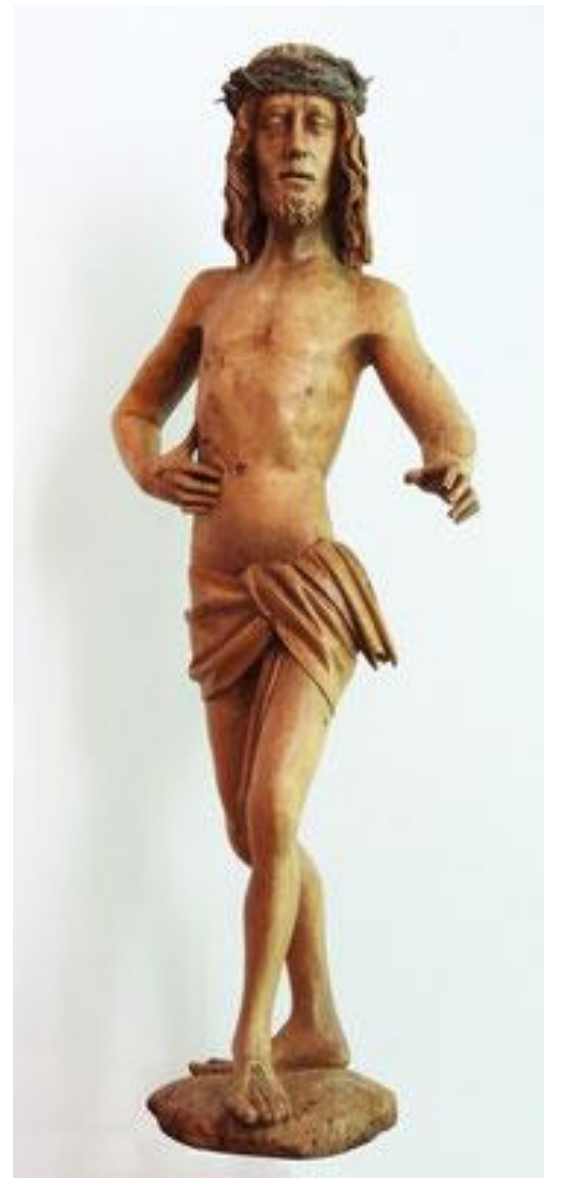

Il. 5. Pracownia Erazma Grassera, Chrystus Odkupiciel Win. Fot. za: dom aukcyjny Maria-Luise HoppGantner Kunsthandel, https://www. hopp-gantner.de/portfolio/

przede wszystkim dzieła powstałe na terenie południowych Niemiec. Można chociażby wskazać figurę Chrystusa Odkupiciela Win z około 1495 r. z pracowni Erazma Grassera (il. 5) ${ }^{49}$. Podobieństwa obu tych

${ }^{49}$ Wystawione na aukcji w: Hopp-Gantner Kunsthandel - https://www.hopp-gantner.de/portfolio/. Składam podziękowania właścicielom domu aukcyjnego Marii-Luise Hopp-Gantner i dr. Benno C. Gantnerowi za pozwolenie na publikację zdjęcia. Na te analogie zwróciła uwagę E. Pilecka, Rzeźba Chrystusa, s. 37. 
realizacji polegają m.in. na analogicznym przedstawieniu postaci kroczącej ku widzowi, z wyciągniętą lewą ręką ${ }^{50}$, o proporcjach ciała i kompozycji bryły stanowiących niemal lustrzane odbicie figury toruńskiej; z podobną dynamiką obrotu wokół osi, analogicznie opracowaną (tak w bryle rzeźbiarskiej, jak i modelunku powierzchni) budową anatomiczną nóg, rąk i korpusu, a także z „tanecznym” wykrokiem nóg i takim samym ustawieniem stóp. Za podobne możemy również uznać nisko zawieszone przepaski biodrowe odsłaniające prawie całe podbrzusze rzeźbionej postaci. Między tymi dziełami zachodzą jednakże różnice - w układzie prawej ręki w dziele Grassera dotykającej boku, w opracowaniu rzeźbiarskim głowy oraz $\mathrm{w}$ perizonium, które w figurze toruńskiej jest bardziej plastyczne i dekoracyjne. Poszukując wzorów dla toruńskiego Chrystusa możemy się odwołać nie tylko do tematycznie i formalnie bliskiego dzieła Grassera, ale też do rzeźby Ukrzyżowanego dłuta Tilmana Riemenschneidera z Museum für Franken w Würzburgu, prezentującej naturalistyczny typ fizjonomii, tak jak w obiekcie toruńskim, $\mathrm{z}$ wyraźnymi podobieństwami w ujęciu głowy i rysów twarzy. Figura Riemenschneidera ma także uplastycznioną górną wargę, długi, prosty nos, mocno uniesione brwi z wyraźnymi dwiema bruzdami V-kształtnymi łuków brwiowych, dwupasmową, rozrzeźbioną (dłutami o różnej szerokości), kędzierzawą brodę, uformowaną w serpentynowe, oddzielone od siebie pukle i analogicznie opracowane pasma włosów ${ }^{51}$. W taki sposób opracowana jest np. rzeźba św. Jana Chrzciciela z warsztatu tegoż mistrza czy Chrystusa z grupy Opłakiwania pochodząca z Maidbronn w Bawariii ${ }^{52}$. Szczególnie bliską analogię dla figury toruńskiej tak pod względem typu ikonograficznego, jak i semantycznego przekazu,

${ }^{50}$ Sens przedstawień typu ikonograficznego Chrystusa Umęczonego i jego treści omawia G. Jurkowlaniec, Chrystus Umęczony, Warszawa 2001, s. 164-165.

${ }^{51}$ Fotografie wykonane przez Alfreda Ehrhardta - Museum für Franken-Staatliches Museum für Kunst- und Kulturgeschichte w Würzburgu (dawniej Mainfränkisches Museum) in der Riemenschneider-Sammlung des Mainfränkischen Museums Würzburg.

52 A. Kleberger, Die Gruppen der Beweinung Christi in Hessenthal und Großostheim, [w:] Tilman Riemenschneider - frühe Werke, Ausstellung im Mainfränkischen Museum Würzburg veranstaltet von der Skulpturengalerie der Staatlichen Museen PreuBischer Kulturbesitz Berlin, der Stadt Würzburg und dem Bezirk Unterfranken vom 5. September bis 1. November 1981, B. Buczynski, F. Buchenrieder, P. Bloch, Regensburg 1981, s. 322-332. 
a także ideału estetyczno-formalnego (ujęcia) - stanowi wspomniana już rzeźba Erazma Grassera z 1495 r. ${ }^{53} \mathrm{~W}$ szczegółach anatomicznych twarzy najbliższe jej są jednak dzieła, które wyszły z pracowni Tilmana Riemenschneidera. Pod względem formalnym twórca naszej figury wywodzi się więc z tradycji rzeźby południowoniemieckiej ${ }^{54}$, najprawdopodobniej w tym środowisku był wykształcony.

Kwestią wymagającą badań jest ustalenie dróg transmisji tych terytorialnie odległych wzorców na ziemię chełmińską i do Torunia, który urósł - po okresie zastoju spowodowanego wojną trzynastoletnią - do rangi prężnego ośrodka wytwórczości snycerskiej ${ }^{55}$. Na drodze jakich przemian mógł ukształtować się styl późnogotyckiej rzeźby w Toruniu? Czy działały w tym czasie tylko lokalne warsztaty? Czy mogli tu przybywać obcy wykonawcy? A może importowano wyroby snycerskie? Szukając odpowiedzi na te pytania najczęściej badacze wskazywali na Gdańsk, który stał się, szczególnie od drugiej połowy XV w., po zrzuceniu zwierzchnictwa krzyżackiego, wielkim tyglem, gdzie pojawiały się dzieła o różnej proweniencji56. Szczególnie bogato udokumentowana jest w materiale zabytkowym działalność w Gdańsku południowoniemieckich snycerzy i kamieniarzy, jak chociażby Mistrza Michała z Augsburga i jego warsztatu, Mistrza Pawła oraz rzeźbiarzy Tilmana Riemenschneidera czy Wita Stwosza ${ }^{57}$. Rozpoznane też zostały przez historyków sztuki importy dzieł $\mathrm{z}$ wielkich nadbałtyckich miast

\footnotetext{
${ }^{53}$ https://www.hopp-gantner.de/portfolio/. Przywołuje tę analogie E. Pilecka, Rzeźba Chrystusa, s. 33-41.

${ }_{54}$ O. Gertrud, Gregor Erhart, Berlin 1943.

${ }^{55} \mathrm{Na}$ przełomie XV/XVI w. w sztuce Torunia dostrzegano w malarstwie i rzeźbie wpływy północnoniemieckie, głównie westfalskie i niderlandzkie. Kruszelnicka wspominała o możliwości przypisania wykonawstwa kilku rzeźb bardzo dobrej klasy warsztatowi niderlandyzującemu, a głównie wymienionemu w źródłach Halsowi Elgerowi, mistrzowi zmarłemu przed $1523 \mathrm{r}$. Wzmianka o nim figuruje w księdze ławniczej Torunia - J. Kruszelnicka, Rzeźba i malarstwo, s. 36-37.

${ }^{56}$ Pytania te stawiała E. Pilecka, Rzeźba Chrystusa, s. 38.

${ }^{57}$ M. Kierkus-Prus, Przekształcenia wzorów graficznych w późnośredniowiecznych retabulach rzeźbionych na terenie Pomorza Wschodniego, [w:] Materiaty sesji naukowej poświęconej pamięci prof. Gwidona Chmarzyńskiego $w$ trzydziesta rocznice śmierci, red. J. Poklewski, Teka Komisji Historii Sztuki, t. X, Toruń 2005, s. 140-148; A. Woziński, Późnogotycka rzeźba monochromatyczna w Prusach, Porta Aurea. Rocznik Instytutu Historii Sztuki Uniwersytetu Gdańskiego, t. 11, 2012, s. 67-106.
} 
hanzeatyckich ${ }^{58}$. Źródłowo poświadczone jest sprowadzanie do Gdańska bezpośrednio z terenów Flandrii i Holandii płyt kamiennych, rzeźb, drewnianych ołtarzy polichromowanych - głównie około 1500 r. i na początku XVI w. ${ }^{59}$ Środowisko gdańskich snycerzy niewątpliwie wpływało na twórczość w Toruniu, ale było jedynie zaczynem zmian zachodzących w końcu XV i na początku XVI w. Pamiętać należy o tym, że warsztaty toruńskie pozostawały długo tradycyjne i u schyłku gotyku chętnie nawiązywały do stylu Ołtarza św. Wolfganga. Ten tradycjonalizm sztuki Torunia drugiej połowy XV w. był świadectwem końca okresu świetności snycerki toruńskiej i najbliższego regionu, co wynikało z różnych uwarunkowań - przede wszystkim zmniejszenia zapotrzebowania na dzieła sztuki ze względu na nasycenie regionu powstałymi wcześniej elementami wystroju wnętrz czy osłabienia ekonomicznego związanego ze wstrząsem wywołanym wojną trzynastoletnią $(1454-1466)^{60}$. W czwartej ćwierci XV w. na ziemi chełmińskiej powstało już zasadniczo mało dzieł ${ }^{61}$. Produkcja artystyczna w Toruniu ruszyła dopiero na przełomie XV/XVI w. i koncentrowała się wokół wspomnianego już tzw. Warsztatu św. Wolfganga, a także Mistrza z Barbarki (figura św. Barbary z 1515 r.) i Mistrza Poliptyku Fromborskiego $(1504 \mathrm{r} \text {. })^{62}$. I właśnie w snycerce regionu na początku XVI w. ponownie sięgnięto do inspiracji południowoniemieckich, a może także do importów, które ożywiły środowisko lokalne (?). Przywoływane

\footnotetext{
${ }^{58}$ E. Pilecka, Rzeźba Chrystusa, s. 37-38.

${ }^{59}$ A. Woziński, Międzynarodowe kontakty artystyczne hanzeatyckiego Gdańska, [w:] Obok. Polska-Niemcy. 1000 lat historii w sztuce, red. M. Omilanowska, współpraca T. Torbus, kuratorka wystawy A. Rottenberg, Berlin 2011, s. 308-313.

${ }^{60}$ A. Błażejewska, Kryzys sztuk plastycznych na obszarze Prus po pokoju toruńskim 1466 roku w kontekście wcześniejszej spuścizny artystycznej tego regionu, [w:] Materiały sesji naukowej poświęconej pamięci prof. Gwidona Chmarzyńskiego w trzydziesta rocznicę śmierci, red. J. Poklewski, Teka Komisji Historii Sztuki, t. X, Torun 2005, s. 60-70; A. Woziński, Późnogotyckie rzeźbione retabula pomiędzy Gdańskiem, Elblagiem, Królewcem a Toruniem w latach 1450-1530, ibid., s.128-140; A. Błażejewska, E. Pilecka, Sztuka średniowieczna, s. 15-186; J. Kruszelnicka, hasło: 25. Chrystus Bolesny (Ubiczowany), [w:] Ars Sacra. Dawna sztuka diecezji toruńskiej. Katalog wystawy Muzeum Okręgowego w Toruniu, red. M. Woźniak, Toruń 1993, s. 46; E. Pilecka, Rzeźba Chrystusa, s. 38.

${ }^{61}$ J. Kruszelnicka, Rzeźba i malarstwo, s. 28-29.

${ }^{62}$ Ibid., s. 28-45.
} 
analogie formalne toruńskiej rzeźby Chrystusa Bolesnego z dziełami snycerki południowoniemieckiej drugiej połowy XV i początku XVI w. wydają się poświadczać taką możliwość. W przekazywaniu tych impulsów pośredniczyć mogły także warsztaty gdańskie, ale nie mamy źródłowego potwierdzenia takich zależności. Ewidentne są natomiast w rzeźbie toruńskiej pokrewieństwa z dziełami Erazma Grassera (ok. 14501518) i Gregora Erharta (1470-1540). Wskazywano też na podobieństwa toruńskich dzieł późnogotyckich do prac Tilmana Riemenschneidera (szczególnie w opracowaniach partii szat) ${ }^{63}$. Czy zapożyczenia te szły tylko drogą pośrednią, przez środowisko gdańskie, w którym obecne były wpływy południowoniemieckie ${ }^{64}$ ? Wykluczano na przykład bezpośrednie wzorowanie się twórcy Tronu Łaski ze Świerczynek na pracach Riemenschneidera ${ }^{65}$. Dostrzeżono jednak w środowiskach gdańskim i toruńskim silne wpływy szwabsko-bawarskie. Sądzono, że figura św. Piotra z Pluskowęs może pochodzić z monachijskiej pracowni Erazma Grassera ${ }^{66}$ lub, jak wskazują na to najnowsze badania, rzeźba ta związana była bezpośrednio z warsztatem Wita Stwosza ${ }^{67}$. Te sugestie wynikały ewidentnie ze spostrzeżenia, iż jest to dzieło właściwie jednostkowe na ziemi chełmińskiej i nie znajdujące żadnych analogii warsztatowych na tym terenie ${ }^{68}$. Te cechy odnajdujemy właśnie u Chrystusa Umęczonego z kościoła Świętojańskiego. Właściwe wydaje się też łączenie omawianego obiektu z krucyfiksem z kościoła NMP w Toruniu

\footnotetext{
${ }^{63}$ Jako przykłady: św. Jan Ewangelista z 1497 r. z kościoła Świętojańskiego w Toruniu; Madonna z Dzieciątkiem z ok. 1500 r. z kościoła Dominikanów pw. św. Mikołaja w Toruniu, obecnie w kościele św. Jakuba; krucyfiks z ok. 1520 r. z kościoła Świętojańskiego w Toruniu - J. Kruszelnicka, hasła: 1. Św. Jan Ewangelista - ryc. 1; 2. Madonna z Dzieciatkiem ryc. 2; 26. Krucyfiks - ryc. 35, [w:] Kultura artystyczna ziemi chetmińskiej w czasach Kopernika, red. Z. Ciara, Toruń 1973, 67-70; 101-103.

${ }^{64}$ A. Woziński, Michał z Augsburga, Mistrz Pawet i epilog rzeźby gotyckiej w Gdań$s k u$, Rocznik Historii Sztuki, t. 27, 2002, s. 20-92.

${ }_{65}$ J. Kruszelnicka, Dwie gotyckie figury, s. 138.

${ }^{66}$ J. Kruszelnicka, Rzeźba i malarstwo, s. 33 oraz il. 13; J. Kruszelnicka, hasło: 12. Św. Piotr - ryc. 13, [w:] Kultura artystyczna ziemi chetmińskiej w czasach Kopernika, s. $81-82$.

${ }^{67}$ A. Soćko, Sztuka w stużbie wiary, [w:] Imagines Medii Aevi. Wystawa z okazji 1050. rocznicy chrztu Polski, Muzeum Narodowe w Poznaniu, Poznań 2016, s. 134.

${ }^{68}$ J. Kruszelnicka, Św. Piotr, s. 81-82.
} 
i z Tronem Łaski ze Świerczynek ${ }^{69}$, ale jako powtórzenie utrwalonych już w nich cech formalnych. Nie można mówić o identyczności „ręki” ich wykonawców. Interesujący nas zabytek nie wydaje się też refleksem sztuki Gdańska z początku XVI w. Jest bardziej „riemenschneiderowski” i „południowoniemiecki”. Analogie bezpośrednie z dziełami Riemenschneidera wykazują w tym czasie także inne rzeźby na obszarze ziemi chełmińskiej: na przykład grupa Ukrzyżowania z katedry w Chełmży ${ }^{70}$. Poświadczają one szczególne upodobanie do naśladownictwa dzieł z tego kręgu artystycznego. Wspominane przez Janinę Kruszelnicką podobieństwa omawianej figury do rzeźby Multschera $z$ Ulm nie są tak bliskie $^{71}$. Przywoływane dzieła uświadamiają nam, że - jak pisała ta badaczka - toruńska rzeźba tego czasu „nie skapitulowała bez reszty przed inwazją sztuki gdańskiej... i usiłowała z nią konkurować" 72 .

Reasumując, możemy stwierdzić, że figura Chrystusa Umęczonego powstała najprawdopodobniej w okresie odrodzenia się twórczości rzeźbiarskiej w Toruniu na przełomie XV/XVI w. ${ }^{73}$, tuż po okresie działalności Warsztatu św. Wolfganga (1497-1506), którego dzieła nie wykraczały poza „poziom poprawnej przeciętności”74. Datować ją można na około 1500 r. Być może jej wykonawca był wykształcony bezpośrednio w środowisku południowoniemieckim lub nawet rzeźbę stamtąd sprowadzono. Dostrzec można, iż Toruń, zachowujący wręcz dużą niezależność

\footnotetext{
${ }^{69}$ Por. jw., a także A. Woziński, Artystyczne i ideowe, s. 203-222, zwłaszcza s. 204. Do sugestywnych podobieństw należą przede wszystkim: smukłość sylwetki, długie ręce i nogi, sposób opracowania zarostu w postaci rozrzeźbionych dwóch pukli oraz wyraźne zaznaczenie siatki użylenia rąk i nóg, ale także analogiczne kształtowanie perizonium. Te cechy dostrzeżone zostały w: J. Kruszelnicka, Chrystus Bolesny, s. 92. Zob. też E. Pilecka, Rzeźba Chrystusa, s. 42.

${ }^{70}$ Za takimi analogiami opowiedziała się J. Kruszelnicka, Dwie gotyckie figury, s. 138-139, wątpiąc tym samym we wpływy rzeźby ze Spiszu, jak sugerowała K. Lejman, Grupa rzeźb późnogotyckich w kościele parafialnym w Chetmży, [w:] Stowarzyszenie Historyków Sztuki Oddziat w Toruniu. Komunikaty na Sesję Naukowa poświęcona dzietom sztuki Pomorza, zorganizowana w 500-lecie Pokoju Toruńskiego, Toruń 1966, s. 76.

${ }^{71}$ J. Kruszelnicka, Chrystus Bolesny, s. 90-92; E. Pilecka, Rzeźba Chrystusa, s. 43.

72 J. Kruszelnicka, Dwie gotyckie figury, s. 146.

${ }^{73}$ Ibid., s. 115-152, gł. 135.

${ }^{74}$ G. Chmarzyński, Sztuka Torunia, s. 507.
} 
od Gdańska ${ }^{75}$, szerzej „otwierał się” w tym czasie na nowe pomysły, sięgając poza własnych wykonawców.

Do doprecyzowania pozostaje kwestia określenia, do jakiego typu ikonograficznego możemy zaliczyć naszą rzeźbę. Prawzorem ikonograficznym Chrystusa Umęczonego były generalnie dwunastowieczne przedstawienia bizantyjskie inspirowane wizerunkiem postaci z Całunu Turyńskiego, wizerunkiem na Mandylionie, być może także motywami ze sceny Ukrzyżowania lub też tekstami liturgicznymi, bądź też uważano, iż jest on bolesnym odpowiednikiem Chrystusa Pantokratora ${ }^{76}$. W sztuce zachodnioeuropejskiej ten typ rozwijał się od połowy XIII stulecia, a reprezentowały go bardzo liczne warianty i mutacje. Według Grażyny Jurkowlaniec, na przełomie XV i XVI w. wizerunki tego typu stają się coraz rzadsze, a w drugiej połowie XVI w. pojawiają się one już wyłącznie w ośrodkach prowincjonalnych ${ }^{77}$. Chrystus przedstawiany był jako żywy, lecz ze znamionami przebytej męki ${ }^{78}$. U schyłku średniowiecza wypierają go inne przedstawienia dewocyjne: Chrystus Zmartwychwstały, Biczowany czy Chrystus Frasobliwy ${ }^{79}$.

Typ ikonograficzny, do którego można zaliczyć omawianą figurę, nie jest oczywisty ${ }^{80}$. Bywa ona określana jako Imago Pietatis, Chrystus Ubiczowany $^{81}$, Vir Dolorum, Mą̇ Boleści, Chrystus Bolesny ${ }^{82}$, Chrystus Umęczony ${ }^{83}$. Choć pojawiło się w literaturze określenie „Chrystus Biczowany”, to pod warstwą przemalowań nie dostrzegano wcześniej śladów opracowania strużek krwi czy zaznaczenia rany w boku ${ }^{84}$. Nie

\footnotetext{
${ }^{75}$ A. Woziński, Michał z Augsburga, s. 89.

${ }^{76}$ Przegląd opinii dotyczących genezy typu ikonograficznego Chrystusa Umęczonego - G. Jurkowlaniec, Chrystus Umęczony, s. 23-25.

${ }^{77}$ Ibid., s. 165.

${ }^{78}$ Ibid., s. 56-58.

${ }^{79}$ Ibid., s. 165.

${ }^{80}$ O typie ikonograficznym E. Pilecka, Rzeźba Chrystusa, s. 34-36.

${ }^{81}$ J. Kruszelnicka, Dwie gotyckie figury, s. 115-152, gł. 137; K. Zalska, Rzeźba późnogotycka, s. 72 n.; J. Kruszelnicka, Rzeźba i malarstwo, s. 24-45.

82 J. Kruszelnicka, Chrystus Bolesny, s. 90; A. Woziński, Artystyczne i ideowe, s. 206, 220.

${ }^{83}$ E. Pilecka, Kościót p.w. św. Jana, s. 172.

${ }^{84}$ J. Kruszelnicka, Chrystus Bolesny, s. 91 . W latach siedemdziesiątych XX w. perizonium określano też jako „srebrzone”, a liczne kity i nawarstwienia przesłaniały oryginalną polichromię gotycką.
} 
można było jednak ich istnienia jednoznacznie wykluczyć ${ }^{85}$. Zagadnienie typu ikonograficznego, do jakiego można zaklasyfikować toruńską rzeźbę, wymaga zatem szerszych studiów porównawczych i uwzględnienia najnowszych ustaleń konserwatorskich. Celem byłoby wyjaśnienie, na drodze jakich transformacji doszło do uformowania odmiany interesującego nas typu ikonograficznego ${ }^{86}$. Skoncentrować się należy jak sądzę - na genezie wizerunków Chrystusa wywodzących się z Konstantynopola czasów Komnenów, z których ewoluowały liczne ujęcia typu Vir Dolorum (Chrystusa Umęczonego) ${ }^{87}$. Zaznaczmy, że typ ikonograficzny Chrystusa Bolesnego, w którym akcent położony jest na moment biczowania (do tego typu zaliczyła figurę toruńską Kruszelnicka ${ }^{88}$ ), występował stosunkowo rzadko i miał inny układ dłoni skrzyżowanych na piersi. Nie były też w nim eksponowane narzędzia męki, a jeżeli występowały, to odgrywały rolę podrzędną wobec idei demonstrowania $\operatorname{ran}^{89}$. W przykładzie toruńskim nie zachowały się w ogóle średniowieczne atrybuty męki - narzędzia do biczowania. Widoczna na zdjęciach „trzcina” (np. w pracy R. Heuera z 1931 r.) była z pewnością nowożytnym dodatkiem ${ }^{90}$, a ujawnione ślady malowanych strużek krwi w oryginalnej warstwie malarskiej są szczątkowe. Brak w figurze wyrzeźbionej i opracowanej plastycznie rany w boku także nie przesądza o zaliczeniu przedstawienia do typu „historycznego”, tj. ukazania Chrystusa w momencie po biczowaniu (a przed śmiercią

\footnotetext{
${ }^{85} \mathrm{~W}$ czasie prac konserwatorskich takie ślady dostrzeżono: J. Ziemlewicz, Dokumentacja prac konserwatorskich, s. 7, 19, 21, 47.

${ }^{86}$ E. Pilecka, Rzeźba Chrystusa, s. 34.

${ }^{87}$ G. Schiller, Ikonographie der christlichen Kunst, Bd. 2, Die Passion Jesu Christi, Gütersloh 1968; T. Dobrzeniecki, Niektóre zagadnienia ikonografii Męża Boleści, Rocznik Muzeum Narodowego w Warszawie, XV.1, Warszawa 1971, s. 7-219; E. Panofsky, Imago pietatis. Przyczynek do historii typów przedstawieniowych. Mąz Boleści i Maryja Pośredniczka, [w:] Średniowiecze, red. E. Panofsky, przeł. G. Jurkowlaniec, A. Kozak, T. Dobrzeniecki, Warszawa 2001, s. 221-290; G. Jurkowlaniec, Chrystus Umęczony, s. 23-25. Tu skrótowe przedstawienie genezy typu oraz szersza literatura tematu.

${ }^{88}$ J. Kruszelnicka, Chrystus Bolesny, s. 91.

${ }^{89}$ Chrystus Bolesny w katedrze w Merseburgu, z drugiej połowy XV w., i na sztychu Rudera. Ibid., s. 92.

${ }^{90} \mathrm{~W}$ wizerunkach Chrystusa Umęczonego pojawiają się różne atrybuty, np. trzcina, rózga, bicz, kielich, wszystkie narzędzia Męki Pańskiej (Arma passionis) - G. Jurkowlaniec, Chrystus Umęczony, s. 39, 75-82.
} 
krzyżową). Rana w boku - chociaż była bardzo istotnym elementem ikonograficznym tego typu przedstawień - w rzeźbach Chrystusa Umęczonego często nie była eksponowana rzeźbiarsko, ale tylko namalowana. Oczywiście nie można w odniesieniu do naszego zabytku jednoznacznie odrzucić klasyfikacji do typu Chrystus Biczowany, ale nie ma też w nielicznych zachowanych zabytkach z przełomu XV/XVI w. żadnych jego typologicznych wyróżników w stosunku do Męża Boleści $i^{91}$. Poza tym Janina Kruszelnicka - na ówczesnym etapie badań historii sztuki - mogła odnosić omawiane dzieło jedynie do zdefiniowanego ikonograficznie typu przedstawień Chrystusa o znanej jej wymowie eucharystycznej, charakterystycznego w XIV i XV w. ${ }^{92}$, i nie znała nowszych studiów nad tematem, powstałych na przełomie XX i XXI w. ${ }^{93}$, a wskazujących na jego soteriologiczne konotacje ${ }^{94}$.

W sensie ikonograficznym rzeźby Chrystusa Umęczonego z przełomu XV/XVI w. prezentują typ tzw. Gnadenbild - Obrazu Łaski, przedstawiającego STAN Chrystusa, a nie MOMENT z Pasji. Nie jest On ukazany jako postać historyczna, ale jako adorowany przez wiernych Zbawiciel, dawca Łaski zbawienia. To jest „Wizerunek Pośredniczący”, przedstawienie skutków Męki, a nie jej ilustracja. Wymowa jest więc taka, że Chrystus jest Pośrednikiem w otrzymaniu Łaski zbawienia. Sens jest zatem soteriologiczny - zbawczy - $\mathrm{i}$ jako taki był akcentowany w przedstawieniach, szczególnie na przełomie XV/XVI w. Dlatego Chrystus w owych wizerunkach ukazuje rany, patrzy na wiernych, wyciąga do nich ręce, odrywa się od krzyża, ,przytula ludzką duszę" ${ }^{95}$. Typ ikonograficzny toruńskiej figury odwołuje się do takiej wykładni przedstawień Umęczonego Zbawiciela. W swym znaczeniu jest też odniesie-

\footnotetext{
${ }^{91}$ E. Pilecka, Rzeźba Chrystusa, s. 34-35.

92 G. Jurkowlaniec, Chrystus Umęczony, s. 23-25. Tu skrótowe omówienie genezy typu.

${ }^{93}$ Mam na myśli prace H. Beltinga, Das Bild und sein Publikum im Mittelalter. From und Funktion früher Bildtafeln der Passion, Berlin 1981; D. Freedberga, The Power of Images. Studies in the History and Theory of Response, Chicago 1989; tegoż, Potęga wizerunków. Studia z historii i teorii oddziaływania, (przekł. E. Klekot), Kraków 2005, czy G. Jurkowlaniec, Chrystus Umęczony.

${ }^{94}$ E. Pilecka, Rzeźba Chrystusa, s. 35.

95 Tego typu przedstawienia figur Chrystusa odnajdujemy w Neumünster w Würzburgu, w Suhl-Heinrichs oraz w Helmstedt w kościele St. Marienberg. E. Pilecka, Rzeźba Chrystusa, s. 35.
} 
niem do koncepcji sądu indywidualnego po śmierci, albowiem to właśnie Ofiara Chrystusa, a w szczególności jego rany, są źródłem odkupienia w momencie sądu ostatecznego ${ }^{96}$. Piotr Skubiszewski w klasyfikacji omawianych wizerunków Vir Dolorum zwracał uwagę właśnie na zasadnicze gesty i układ rąk Chrystusa ${ }^{97}$. Wcześniej - w XIV/XV w. bardziej eksponowany był w przedstawieniach Chrystusa Umęczonego sens eucharystyczny: Chrystus uobecniał ofiarę miłosierdzia - tak, jak uobecniała ją msza święta. Obraz Chrystusa Umęczonego był wówczas sumarycznym obrazem mszy świętej. Soteriologiczne rozumienie obrazu Chrystusa Umęczonego sprawiło, że obrazujące Go figury pojawiły się w szafach ołtarzowych - np. w Ołtarzu Złotników w kościele Marii Magdaleny we Wrocławiu - lub w ich zwieńczeniach. Umieszczano je też w predellach, na epitafiach oraz w malowidłach ściennych. Analogie typologiczno-formalne utwierdzają nas $\mathrm{w}$ atrybucji ikonograficznej rzeźby toruńskiej jako Gnadenbild - Chrystus Umęczony, a nie Biczowany. Analogiczny gest ukazywania rany w boku lub „wyjmowania” hostii czy wskazywania na ranę znajdujemy w późnogotyckiej rzeźbie Męża Boleści z około 1480 r. z terenu Szwajcarii (orzech polerowany, nie polichromowany $)^{98}$. Prezentowany przezeń typ ikonograficzny jest tym bardziej bliski zabytkowi toruńskiemu, że podobne jest opracowanie detali (a więc i prawdopodobnie pokrewna proweniencja regionalna): np. broda dwupasmowa rozdzielona na osi, usta półotwarte i odsłaniające zęby, dwuwałkowa korona cierniowa ${ }^{99}$. Figura Męża Umęczonego z kościoła Świętojańskiego jest pod względem typu ikonograficznego tradycyjna, gdyż - jak wspomniano - popularniejszy stawał się już w końcu XV stulecia typ Chrystusa Zmartwychwstalego, Ecce Homo lub ahistorycznego, dewocyjnego Chrystusa Frasobliwego ${ }^{100}$. W figurach tego typu przenikały się wzajemnie rozmaite funkcje liturgiczne zależne od kalendarza świąt, przede wszystkim Pasji, ale także

\footnotetext{
${ }^{96}$ Ibid.

${ }^{97}$ P. Skubiszewski, Cristo, [w:] Enciclopedia dell'Arte Medievale, t. V, Roma 1994, s. 493-521; tenże, Figurazioni devozionali, ibid., t. VI, Roma 1995, s. 177-195.

98 http://www.mahf.ch/mahf/de/pub/museum_fuer_kunst/sammlung/dauerausstellung/skulptur_und_malerei_um_1500.htm; E. Pilecka, Rzeźba Chrystusa, s. 42.

${ }^{99}$ Ibid.

${ }^{100}$ Ibid., s. 36, MKZ, sygn. 7311.
} 
pozaliturgiczne, gdzie figury stymulowały modlitewne uniesienia ${ }^{101}$. U Chrystusa toruńskiego brak wyraźnie zaznaczonej rany w prawym boku, co wyklucza jego przynależność do typu Chrystusa Eucharystycznego: $\mathrm{z}$ kielichem $\mathrm{w}$ ręce lub wyjmującego $\mathrm{z}$ rany hostię ${ }^{102}$. Nasza rzeźba, ze względu na precyzję oddania szczegółów anatomicznych twarzy, mięśni, użylenia, przeznaczona jest raczej do oglądu z bliska, kameralnego, a nie grupowego. Natomiast takie cechy figury, jak jej wychodzenie ku oglądającemu, układ rąk skierowanych przed siebie i czyniących gest „ujmowania” (jak to określiła Janina Kruszelnicka) i skierowanie palców lewej dłoni w stronę wiernego („choć ten gest nie jest tak jednoznaczny"103), każą nam uznać, iż była to prawdopodobnie rzeźba dewocyjna (il. 1). Próba zagarniania rękoma przestrzeni przed sobą w toruńskiej rzeźbie nasuwa pewne skojarzenia z tzw. „krucyfiksami obejmującymi"104. Jak trafnie zauważył Przemysław Waszak, układ rąk Ukrzyżowanego w tego typu wizerunkach nie jest ani oczywisty, ani jasny ${ }^{105}$. Właściwie nie widać osoby obejmowanej, tylko przestrzeń, która może odnosić się do świętego, zwykłego wiernego lub też duszy przytulonej przez cierpiącego Chrystusa. W toruńskiej rzeźbie jedynie układ prawej dłoni jest oczywisty, ponieważ wskazuje on, iż znajdował się $\mathrm{w}$ niej jakiś przedmiot związany $\mathrm{z}$ męką; być może była to rózga lub też dyscyplina ${ }^{106}$. „Niejednoznaczny” gest lewej dłoni, z dwoma palcami skierowanymi do przodu (il. 1), może symbolizować próbę nawiązania przez Chrystusa dialogu z konkretnym wiernym poprzez jego

${ }^{101}$ M. Jakubek-Raczkowska, Tu ergo flecte genua tua. Sztuka a praktyka religijna świeckich $w$ diecezjach pruskich państwa zakonu krzyżackiego do połowy XV wieku, Pelplin 2014, s. 548.

102 J. Kruszelnicka, Chrystus Bolesny, s. 91; T. Dobrzeniecki, Niektóre zagadnienia, s. 7-219.

103 J. Kruszelnicka, Chrystus Bolesny, s. 91.

${ }^{104}$ G. Osten von der, Der Schmerzensmann: Typengeschichte eines deutschen Andachtsbildwerkes von 1300 bis 1600, Berlin 1935, s. 49 n.; G. Jurkowlaniec, Chrystus Umęczony, s. 36, 37; E. Panofsky, Imago pietatis, s. 246, przyp. 69; P. Waszak, Gotyckie „krucyfiksy obejmujace" $i$ ich snycerskie przykłady z Würzburga, Suhl-Heinrichs i Helmstedt, Sztuka i Kultura, t. 2, 2014, s. 47-80.

${ }^{105}$ P. Waszak, Gotyckie „krucyfiksy obejmujace”, s. 47-80.

106 J. Kruszelnicka, Chrystus Bolesny, s. 91. 
wskazanie ${ }^{107}$ i zwrócenie się do niego słowami: „cierpiałem za ciebie cierpię za ciebie - co robisz dla mnie", wzbudzając w nim nadzieję na odkupienie grzechów. Jak trafnie zauważa Hans Belting, rozmowa, którą chciano prowadzić z obrazem lub rzeźbą kultową, w wypadku wizerunku dewocyjnego obecna jest już w samym dziele. Narracja nie przedstawia żadnego rzeczywistego wydarzenia, lecz ożywia postacie w taki sposób, że można sobie wyobrazić ich uczucia ${ }^{108}$. W tym kontekście zmartwychwstały-żywy Chrystus umożliwia wiernemu pogłębienie uczuć żalu nad Zbawicielem aż do uczucia współcierpienia z Nim, ale także upewnia wyznawcę, że po swej śmierci żyje On i działa dla ratowania grzeszników ${ }^{109}$. Wysłuchuje także, jako niewidzialny świadek, spowiedzi, które często odbywały się w owym czasie w świątyniach za ołtarzem głównym. To dlatego na zewnętrznych skrzydłach retabulów tak często pojawiały się malowane sceny z Sądem Ostatecznym, Ukrzyżowaniem, z przedstawieniem Męża Boleści lub podobne tematy służące do pobudzania doznań religijnych ${ }^{110}$.

Do rozstrzygnięcia pozostaje kwestia pierwotnego przeznaczenia i lokalizacji omawianej rzeźby w przestrzeni kościoła Świętojańskiego w Toruniu. Wnętrze tej świątyni w drugiej połowie XV i na początku XVI w. zostało wypełnione licznymi dziełami, będącymi świadectwem religijnych nastrojów epoki, życia bractw religijnych, komemoracji czy też kultu świętych. Kościół wypełniał się ołtarzami, rzeźbami, malowidłami tablicowymi ustawianymi i zawieszanymi w korpusie oraz w kaplicach naw bocznych w wyniku licznych fundacji ${ }^{111}$. Wprowadzano także nowe tematy $\mathrm{w}$ malowidłach ściennych. Zmiany następujące w wyposażeniu świątyni Świętojańskiej zostały omówione kilkakrotnie (na podstawie źródeł pisanych oraz zachowanego materiału zabytko-

${ }^{107}$ H. Belting, Obraz i kult. Historia obrazu przed epoka sztuki, przeł. T. Zatorski, Gdańsk 2010, s. 475.

${ }^{108}$ Ibid., s. 475.

${ }^{109}$ E. Panofsky, Imago pietatis, s. 245.

${ }^{110}$ R. Suckale, Der mittelalterliche Kirchenbau im Gebrauch als Ort der Bilder, [w:] Stil und Funktion. Ausgewählt Schriften zur Kunst des Mittelalters, hrsg. P. Schmidt, G. Wedekind, München 2003, s. 400. Wiele przykładów zamieścił T. Dobrzeniecki, Niektóre zagadnienia, s. 7-219.

${ }^{111}$ E. Pilecka, Kościót p.w. św. Jana, s. 170. 
wego) przez Michała Woźniaka ${ }^{112}$. W przypadku naszej rzeźby badacze sugerowali jej pochodzenie, jak już wspomniano powyżej, $\mathrm{z}$ altare vetustum kaplicy szyperskiej, ze zwieńczenia tzw. ołtarza Świętej Rodziny, z ołtarza Korony Cierniowej, z kaplicy Bożego Ciała, bądź też uważano, że była ona samodzielną figurą dewocyjną ${ }^{113}$. W pierwszym $\mathrm{z}$ retabulów miały się jednak znajdować wyłącznie rzeźby kamienne ex saxo - o czym wspominał w XVII w. autor wizytacji bp Andrzej Olszowski ${ }^{114}$. Tymczasem omawiany przez nas zabytek wykonany jest $\mathrm{z}$ drewna, co z pewnością nie umknęłoby jego uwadze. Ten fakt przeczy pochodzeniu rzeźby $\mathrm{z}$ ołtarza $\mathrm{w}$ kaplicy szyperskiej. $\mathrm{Z}$ drugiego $\mathrm{z}$ wymienionych retabulów - Świętej Rodziny - pochodzić mają tablice eksponowane obecnie w nawie północnej kościoła z przedstawieniem Narodzin Chrystusa, Obrzezaniem oraz Zwiastowaniem ${ }^{115}$. Sugerując takie związanie figury Chrystusa z ołtarzem, opierano się jedynie na zbliżonym czasie powstania obydwu zabytków i pewnym podobieństwie stylu malowideł na skrzydłach ołtarza i figury Chrystusa ${ }^{116}$. Nasza rzeźba miałaby znajdować się w zwieńczeniu architektoniczno-rzeźbiarskim tego retabulum. Dla poparcia tej tezy można przywołać m.in. realizacje $\mathrm{z}$ przełomu XV/XVI w., w których także umieszczono figurę Umęczonego Zbawiciela w strukturach wieńczących ołtarz, takich jak np.: nastawa wykonana przez Michaela Erharta dla ołtarza z kościoła w Blaubeuren $\mathrm{z}$ lat 1490-1494, retabulum ołtarza w kościele św. Jakuba w Rothenburgu z 1499 r., nastawa z kościoła w Creglingen Tilmana Riemenschneidera $\mathrm{z}$ lat $1505-1510^{117}$. Temu przypisaniu figury do

${ }^{112} \mathrm{O}$ wyposażeniu kościoła Świętojańskiego w Toruniu i jego przestrzeni liturgicznej: M. Woźniak, Przestrzeń liturgiczna, s. 391-409; M. Woźniak, Ottarze w przestrzeni liturgicznej kościoła Świętojańskiego w Toruniu, [w:] Dzieje i skarby kościoła Świętojańskiego w Toruniu, red. K. Kluczwajd, M. Woźniak, Toruń 2002, s. 273-294.

${ }^{113}$ J. Kruszelnicka, Chrystus Bolesny, s. 90-92; M. Woźniak, Przestrzeń liturgiczna, s. 402-403; E. Pilecka, Kościót p.w. św. Jana, s. 172; A. Błażejewska, E. Pilecka, Sztuka średniowieczna, s. 169.

${ }^{114}$ Visitationes Episcopatus Culmensis Andrea Olszowski episcopo A. 1667-1672 factae, wyd. B. Czapla, Fontes Towarzystwa Naukowego w Toruniu 6-10, Torun $1902-$ 1906, tu t. 7, 1903, s. 195-216; M. Woźniak, Przestrzeń liturgiczna, s. 403; A. Błażejewska, E. Pilecka, Sztuka średniowieczna, s. 169.

115 J. Domasłowski, Wyposażenie wnętrza, s. 150.

116 J. Kruszelnicka, Chrystus Bolesny, s. 91.

117 G. Jurkowlaniec, Chrystus Umęczony, s. 132. 
ołtarza Świętej Rodziny przeczy jednak fakt, co zauważył Michał Woźniak, iż Strzesz nie wymienia tablicy z przedstawieniem Narodzin Chrystusa, Obrzezaniem oraz Zwiastowaniem przy opisie tego ołtarza. Bardziej prawdopodobne jest, że samo malowane skrzydło pochodzi z kościoła Mariackiego, skąd w pierwszej połowie XVII w. przeniesione zostało do kościoła Świętojańskiego. Stanowiło ono prawdopodobnie część retabulum składającego się jedynie z malowanych tablic. W jego części środkowej znajdować się miało wyobrażenie Maryi w krzewie gorejącym, a w stanie zamkniętym - wspomniane Narodziny Chrystusa, Obrzezanie oraz Zwiastowanie ${ }^{118}$. Struktura ołtarza nie pozwalałaby więc na ustawienie w jej zwieńczeniu interesującej nas rzeźby. Należy zatem uznać, iż toruński Chrystus z fary staromiejskiej pełnił funkcję rzeźby dewocyjnej przymocowanej najprawdopodobniej do deski-zaplecka - na co wskazuje prosto ucięta, tylna krawędź cokołu pod stopami Chrystusa - ustawionej przy ścianie, na konsoli lub też w szafie ołtarzowej ${ }^{119}$, w którejś z kaplic bocznych kościoła, co jednoznacznie niejako potwierdza rzeźbiarskie opracowanie tyłu figury.

Szczegółową analizę zabytku umożliwiła przeprowadzona w $2018 \mathrm{r}$. konserwacja ujawniająca warstwę pierwotnej polichromii i niewidoczne wcześniej szczegóły modelunku rzeźbiarskiego. Możemy z pewnością stwierdzić, że dzieło powstało na przełomie XV/XVI w., pod wyraźnym wpływem twórczości warsztatów południowoniemieckich i takich mistrzów, jak Tilman Riemenschneider, Erazm Grasser i Gregor Erhart. Reprezentuje jeden $\mathrm{z}$ wariantów ikonograficznych przedstawień w typie Umęczonego Chrystusa - żywego, z otwartymi oczami, ale bez charakterystycznych dla tego tematu wyraźnych śladów przebytej męki. $\mathrm{Z}$ pewnością było fundacją wpisującą się $\mathrm{w}$ duchowy klimat późnośredniowiecza i prywatnej dewocji. I chociaż jego obecne miejsce w kaplicy Kopernika nie jest zapewne pierwotne, to kameralność ekspozycji tej rzeźby i sposób jej prezentacji, w której istotną rolę odgrywa wysokość zawieszenia konsoli i autentyzm odrestaurowanej kolorystyki, osadza ją w klimacie średniowiecznego wnętrza sakralnego.

${ }_{118}$ M. Woźniak, Przestrzeń liturgiczna, s. 403.

119 A. Woziński, Multiplicity and Unity, s. 65. O takiej funkcji ołtarzy J. Kerosen, Staging the Liturgy. The Medieval Altarpiece in the Iberian Peninsula, Leuven 2009, s. $350 \mathrm{n}$. - za wskazanie tej publikacji składam podziękowania recenzentowi artykułu. 


\section{Bibliografia}

Źródła archiwalne

Visitationes Episcopatus Culmensis Andrea Olszowski episcopo A. 1667-1672 factae, ed. B. Czapla, Fontes Towarzystwa Naukowego w Toruniu 6-10, Torun 1902-1906.

Pilecka E., Rzeźba Chrystusa w typie ikonograficznym Chrystusa Umęczonego - Mąż Boleści z kaplicy Kopernika w kościele św. Janów w Toruniu (obecnej katedrze), [w:] Dokumentacja prac konserwatorskich i restauratorskich przy elementach wyposażenia wnętrza kaplicy tzw. Kopernikowskiej w Toruńskiej katedrze p.w. św. Jana Chrzciciela i św. Jana Ewangelisty, red. J. Ziemlewicz, Torun 2017, s. 29-46, MKZ, sygn. 7311.

Ziemlewicz J., Dokumentacja prac konserwatorskich i restauratorskich przy elementach wyposażenia wnętrza kaplicy tzw. Kopernikowskiej w Toruńskiej katedrze p.w. św. Jana Chrzciciela i św. Jana Ewangelisty, Toruń 2017, MKZ, sygn. 7311.

Publikacje

Belting H., Das Bild und sein Publikum im Mittelalter. Form und Funktion früher Bildtafeln der Passion, Berlin 1981.

Belting H., Obraz i kult. Historia obrazu przed epoka sztuki, przeł. T. Zatorski, Gdańsk 2010.

Błażejewska A., Kryzys sztuk plastycznych na obszarze Prus po pokoju toruńskim 1466 roku w kontekście wcześniejszej spuścizny artystycznej tego regionu, [w:] Materiały sesji naukowej poświęconej pamięci prof. Gwidona Chmarzyńskiego w trzydziesta rocznice śmierci, red. J. Poklewski, Teka Komisji Historii Sztuki, t. X, Torun 2005, s. 60-70.

Błażejewska A., Pilecka E., Sztuka średniowieczna, [w:] A. Błażejewska, K. Kluczwajd i inni, Dzieje sztuki Torunia, Toruń 2009.

Chmarzyński G., Toruń dawny i dzisiejszy, Torun 1933.

Chmarzyński G., Sztuka w Toruniu - zarys dziejów, [w:] Dzieje Torunia, red. K. Tymieniecki, Torun 1933.

Chmarzyński G., Sztuka w Toruniu. Zarys dziejów, [w:] Gwido Chmarzyński i jego dzieło Sztuka w Toruniu, red. E. Okoń, Toruń 2014, s. 49-120.

Dettloff Sz., Rzeźba polska do początku XVIII w., [w:] Wiedza o Polsce, t. II, Warszawa 1932.

Dobrowolski T., Wystawa polskiej sztuki gotyckiej w Warszawie, Rocznik Krakowski, t. XXIV, Kraków 1935, s. 208-230.

Dobrzeniecki T., Niektóre zagadnienia ikonografii Męża Boleści, Rocznik Muzeum Narodowego w Warszawie, XV.1, Warszawa 1971, s. 7-219. 
Domasłowski J., Wyposażenie wnętrza, [w:] Bazylika katedralna Świętych Janów w Toruniu, red. M. Biskup, Toruń 2003, s. 109-228.

Freedberg D., The Power of Images. Studies in the History and Theory of Response, Chicago 1989.

Freedberg D., Potęga wizerunków. Studia z historii i teorii oddziatywania (przekł. E. Klekot), Kraków 2005.

Gertrud O., Gregor Erhart, Berlin 1943.

Heuer R., Die Werke der bildenden Kunst und des Kunstgewerbes in Thorn bis zum Ende des Mittelalters, Mitteilungen des Coppernicus-Vereins für Wissenschaft und Kunst zu Thorn, H. 24, Thorn 1916.

Jakubek-Raczkowska M., Tu ergo flecte genua tua. Sztuka a praktyka religijna świeckich $w$ diecezjach pruskich państwa zakonu krzyżackiego do połowy XV wieku, Pelplin 2014.

Jurkowlaniec G., Chrystus Umęczony, Warszawa 2001.

Kerosen J., Staging the Liturgy. The Medieval Altarpiece in the Iberian Peninsula, Leuven 2009.

Kierkus-Prus M., Przekształcenia wzorów graficznych w późnośredniowiecznych retabulach rzeźbionych na terenie Pomorza Wschodniego, [w:] Materiaty sesji naukowej poświęconej pamięci prof. Gwidona Chmarzyńskiego w trzydziesta rocznicę śmierci, red. J. Poklewski, Teka Komisji Historii Sztuki, Torun 2005, s. 140-148.

Kleberger A., Die Gruppen der Beweinung Christi in Hessenthal und Großostheim, [w:] Tilman Riemenschneider - frühe Werke, Ausstellung im Mainfränkischen Museum Würzburg veranstaltet von der Skulpturengalerie der Staatlichen Museen Preußischer Kulturbesitz Berlin, der Stadt Würzburg und dem Bezirk Unterfranken vom 5. September bis 1. November 1981, B. Buczynski, F. Buchenrieder, P. Bloch, Regensburg 1981, s. 322-332.

Kruszelnicka J., Dwie gotyckie figury św. Barbary z kaplicy w Barbarce pod Toruniem, Rocznik Toruński, t. II, z. 3-4, 1967, s. 115-151.

Kruszelnicka J., Rzeźba i malarstwo, [w:] Kultura artystyczna ziemi chetmińskiej w czasach Kopernika, red. Z. Ciara, Toruń 1973, s. 24-45.

Kruszelnicka J., hasła: 1. Św. Jan Ewangelista - ryc. 1; 2. Madonna z Dzieciątkiem - ryc. $2 ; 12$. Św. Piotr - ryc. 13; 18. Chrystus Bolesny - ryc. 22; 26. Krucyfiks - ryc. 35, [w:] Kultura artystyczna ziemi chetmińskiej w czasach Kopernika, red. Z. Ciara, Toruń 1973, s. 67-70, 81-82, 90-92, 101-103.

Kruszelnicka J., hasło: 25. Chrystus Bolesny (Ubiczowany), [w:] Ars Sacra. Dawna sztuka diecezji toruńskiej. Katalog wystawy Muzeum Okręowego w Toruniu, red. M. Woźniak, Toruń 1993, s. 46. 
Lejman K., Grupa rzeźb późnogotyckich w kościele parafialnym w Chetmży, [w:] Stowarzyszenie Historyków Sztuki Oddział w Toruniu. Komunikaty na Sesje Naukowa poświęcona dziełom sztuki Pomorza, zorganizowana w 500-lecie Pokoju Toruńskiego, Toruń 1966, s. 76-79.

Mańkowski T., Sprawozdania z posiedzeń za rok 1938, Posiedzenie z dnia 20 października 1938, praca pt. Do dziejów rzeźby późnogotyckiej (Miklas Haberschrak), Prace Komisji Historii Sztuki, t. VIII, z. II, 1946, s. 252-261.

Osten von der G., Der Schmerzensmann: Typengeschichte eines deutschen Andachtsbildwerkes von 1300 bis 1600, Berlin 1935.

Panofsky E., Imago pietatis. Przyczynek do historii typów przedstawieniowych. Mąż Boleści i Maryja Pośredniczka, [w:] Średniowiecze, red. E. Panofsky, przeł. G. Jurkowlaniec, A. Kozak, T. Dobrzeniecki, Warszawa 2001, s. 221-290.

Pilecka E., Kościót p.w. św. Jana Chrzciciela i św. Jana Ewangelisty w Toruniu w okresie średniowiecza jako wizualizacja świadomości społecznej, [w:] Dzieje i skarby kościoła Świętojańskiego w Toruniu, red. K. Kluczwajd, M. Woźniak, Toruń 2002, s. 119-176.

Pilecka E., Die Pfarrkirche St. Johannis zu Thorn als Abbild der sozialen Sinnesart des mittelalterlichen Bürgertums, [w:] Licht und Farbe in der mittelalterlichen Backsteinarchitektur des südlichen Ostseeraums (Studien zur Backsteinarchitektur), Bd. 7, hrsg. E. Badstübner, D. Schumann, Berlin 2005, s. 408-436.

Pilecka E., Dzieje sztuki Torunia - stare i nowe ujęcia problemu. Refleksje na marginesie opracowań sztuki miasta profesora Gwidona Chmarzyńskiego, [w:] Gwido Chmarzyński i jego dzieło Sztuka w Toruniu, red. E. Okoń, Toruń 2014, s. 29-44.

Raczkowski J., Jakubek-Raczkowska M., Gotyckie rzeźby z kościoła w Świerczynkach. Przyczynek do badań nad średniowiecznym dziedzictwem Torunia, [w:] Stare i nowe dziedzictwo Torunia, red. J. Raczkowski, t. 1, Toruń 2013, s. 108-125.

Schiller G., Ikonographie der christlichen Kunst, Bd. 2, Die Passion Jesu Christi, Gütersloh 1968.

Skubiszewski P., Cristo, [w:] Enciclopedia dell'Arte Medievale, t. V, Roma 1994, s. 493-521.

Skubiszewski P., Figurazioni devozionali, [w:] Enciclopedia dell'Arte Medievale, t. VI, Roma 1995, s. 177-195.

Soćko A., Sztuka w stużbie wiary, [w:] Imagines Medii Aevi. Wystawa z okazji 1050. rocznicy chrztu Polski, Muzeum Narodowe w Poznaniu, Poznań 2016, s. 134. 
Suckale R., Der mittelalterliche Kirchenbau im Gebrauch als Ort der Bilder, [w:] Stil und Funktion. Ausgewählte Schriften zur Kunst des Mittelalters, hrsg. P. Schmidt, G. Wedekind, München 2003, s. 391-408.

Walicki M., Polska sztuka gotycka, Katalog wystawy, Warszawa 1935.

Waszak P., Gotyckie „,krucyfiksy obejmujace” $i$ ich snycerskie przykłady z. Würzburga, Suhl-Heinrichs i Helmstedt, Sztuka i Kultura, t. 2, 2014, s. 47-80.

Woziński A., Michał z Augsburga, Mistrz Paweł i epilog rzeźby gotyckiej w Gdańsku, Rocznik Historii Sztuki, t. 27, 2002, s. 5-92.

Woziński A., Artystyczne i ideowe aspekty późnogotyckiego krucyfiksu w pofranciszkańskim kościele Mariackim w Toruniu, [w:] Dzieje i skarby kościoła Mariackiego w Toruniu. Materiały z konferencji przygotowanej przez Toruński Oddział Stowarzyszenia Historyków Sztuki przy współpracy Instytutu Zabytkoznawstwa i Konserwatorstwa Uniwersytetu Mikołaja Kopernika (Toruń, 14-16 kwietnia 2005), red. naukowa K. Kluczwajd, Toruń 2005, s. 203-222.

Woziński A., Multiplicity and Unity. The Faces of Sculpture in Prussia between ca. 1450 and 1530, Acta Historiae Artium Balticae, Vol. 1, 2005, s. 51-74.

Woziński A., Późnogotyckie rzeźbione retabula pomiędzy Gdańskiem, Elblagiem, Królewcem a Toruniem w latach 1450-1530, [w:] Materiały sesji naukowej poświęconej pamięci prof. Gwidona Chmarzyńskiego w trzydziesta rocznice śmierci, red. J. Poklewski, Teka Komisji Historii Sztuki, t. X, Toruń 2005, s. 128-139.

Woziński A., On the Role of Engravings in Late Gothic Sculpture in Prussia, [w:] Kunst- und Kulturgeschichte im Baltikum. Studien zur Kunstgeschichte Kurlands, Homburger Gespräch 2008, H. 25, hrsg. L. O. Larsson, Kiel 2009, s. 7-34.

Woziński A., Międzynarodowe kontakty artystyczne hanzeatyckiego Gdańska, [w:] Obok. Polska-Niemcy. 1000 lat historii w sztuce, red. M. Omilanowska, współpraca T.Torbus, kuratorka wystawy A. Rottenberg, Berlin 2011, s. 308-313.

Woziński A., Późnogotycka rzeźba monochromatyczna w Prusach, Porta Aurea. Rocznik Instytutu Historii Sztuki Uniwersytetu Gdańskiego, t. 11, 2012, s. 67-106.

Woźniak M., Przestrzeń liturgiczna kościoła p.w. św. Jana Chrzciciela i św. Jana Ewangelisty, [w:] Argumenta, articuli, quaestiones. Studia z historii sztuki średniowiecznej. Księga jubileuszowa dedykowana Marianowi Kutznerowi, red. A. Błażejewska, E. Pilecka Toruń 1999, s. 391-409. 
Woźniak M., Ottarze w przestrzeni liturgicznej kościoła świętojańskiego w Toruniu, [w:] Dzieje i skarby kościoła Świętojańskiego w Toruniu, red. K. Kluczwajd, M. Woźniak, Toruń 2002, s. 273-294.

Zalska K., Rzeźba późnogotycka w kościele parafialnym w Świerczynkach, [w:] Komunikaty na Sesję Naukowa poświęcona dziełom sztuki Pomorza, zorganizowana w 500-lecie Pokoju Toruńskiego, Toruń 1966, s. 72-75.

Zimmermann A., Jesus Christus als ,, Schmerzensmann” in hoch- und spätmittelalterlichen Darstellungen der bildenden Kunst: eine Analyse ihres Sinngehalts, Martin-Luther-Universität Halle-Wittenberg, dysertacja obroniona 27 XI 1997 r., http://sundoc.bibliothek. uni-halle.de/diss-online/97/98H110/, dostęp 14 X 2018 r. 